\title{
Neural crest cell-derived pericytes act as pro-angiogenic cells in human neocortex development and gliomas
}

\author{
Francesco Girolamo ${ }^{1 *+}\left(\mathbb{D}\right.$, Ignazio de Trizio ${ }^{1,2+}$, Mariella Errede ${ }^{1 \dagger}$, Giovanna Longo ${ }^{3}$, Antonio d'Amati ${ }^{1,4}$ and \\ Daniela Virgintino ${ }^{1}$
}

\begin{abstract}
Central nervous system diseases involving the parenchymal microvessels are frequently associated with a'microvasculopathy', which includes different levels of neurovascular unit (NVU) dysfunction, including blood-brain barrier alterations. To contribute to the understanding of NVU responses to pathological noxae, we have focused on one of its cellular components, the microvascular pericytes, highlighting unique features of brain pericytes with the aid of the analyses carried out during vascularization of human developing neocortex and in human gliomas. Thanks to their position, centred within the endothelial/glial partition of the vessel basal lamina and therefore inserted between endothelial cells and the perivascular and vessel-associated components (astrocytes, oligodendrocyte precursor cells (OPCs)/NG2-glia, microglia, macrophages, nerve terminals), pericytes fulfil a central role within the microvessel NVU. Indeed, at this critical site, pericytes have a number of direct and extracellular matrix molecule- and soluble factormediated functions, displaying marked phenotypical and functional heterogeneity and carrying out multitasking services. This pericytes heterogeneity is primarily linked to their position in specific tissue and organ microenvironments and, most importantly, to their ontogeny. During ontogenesis, pericyte subtypes belong to two main embryonic germ layers, mesoderm and (neuro)ectoderm, and are therefore expected to be found in organs ontogenetically different, nonetheless, pericytes of different origin may converge and colonize neighbouring areas of the same organ/ apparatus. Here, we provide a brief overview of the unusual roles played by forebrain pericytes in the processes of angiogenesis and barriergenesis by virtue of their origin from midbrain neural crest stem cells. A better knowledge of the ontogenetic subpopulations may support the understanding of specific interactions and mechanisms involved in pericyte function/dysfunction, including normal and pathological angiogenesis, thereby offering an alternative perspective on cell subtype-specific therapeutic approaches.
\end{abstract}

Keywords: Human brain development, Prosencephalon, Microvessels, Pericytes, Neural crest cells, Tunnelling nanotubes, Angiogenesis, Blood-brain barrier, Human gliomas

\footnotetext{
*Correspondence: fgirolamo13@gmail.com

${ }^{\dagger}$ Francesco Girolamo, Ignazio de Trizio and Mariella Errede contributed equally to this work

${ }^{1}$ Department of Basic Medical Sciences, Neuroscience and Sensory Organs, Human Anatomy and Histology Unit, University of Bari School of Medicine, Bari, Italy

Full list of author information is available at the end of the article
}

\begin{abstract}
Background
The Rouget cells, firstly described by Charles-Marie Benjamin Rouget in the late 19th century [1], were later denoted as pericytes (PCs) [2]. They are described as vascular cells that, at the level of the microvessel segments (precapillary arterioles, capillary, and postcapillary venules) of the vascular tree, wrap around the endothelial cells (ECs), being retained within the vessel basal lamina,
\end{abstract}

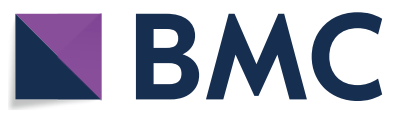

(c) The Author(s) 2021. This article is licensed under a Creative Commons Attribution 4.0 International License, which permits use, sharing, adaptation, distribution and reproduction in any medium or format, as long as you give appropriate credit to the original author(s) and the source, provide a link to the Creative Commons licence, and indicate if changes were made. The images or other third party material in this article are included in the article's Creative Commons licence, unless indicated otherwise in a credit line to the material. If material is not included in the article's Creative Commons licence and your intended use is not permitted by statutory regulation or exceeds the permitted use, you will need to obtain permission directly from the copyright holder. To view a copy of this licence, visit http://creativeco mmons.org/licenses/by/4.0/. The Creative Commons Public Domain Dedication waiver (http://creativecommons.org/publicdomain/ zero/1.0/) applies to the data made available in this article, unless otherwise stated in a credit line to the data. 
that is known to be formed by two layers, pertaining to ECs and astrocytes, respectively. Herein, the term 'basal lamina' is used instead of 'basement membrane', since brain microvessels only show a 'basal lamina' without the 'lamina reticularis' made up by fibrillar collagens, type I, III, and V. After the pioneering descriptions of brain PCs' morphology in primates, including humans, gained by electron transmission microscopy (TEM) [3, 4], the emergence of scanning electron microscopy (SEM) has provided, together with subsequent $3 \mathrm{D}$ reconstructions by TEM serial sections [5, 6], a complete rendering of the 3D morphology and relationships of PCs (Figs. 1, 2). PCs show a prominent nuclear region bulging out on the abluminal vessel side, two longitudinally oriented primary processes sending out transversely arranged secondary processes and additional flat, finger-like, protrusions that interdigitate to fill the remaining gaps. As a consequence of their location within the neurovascular
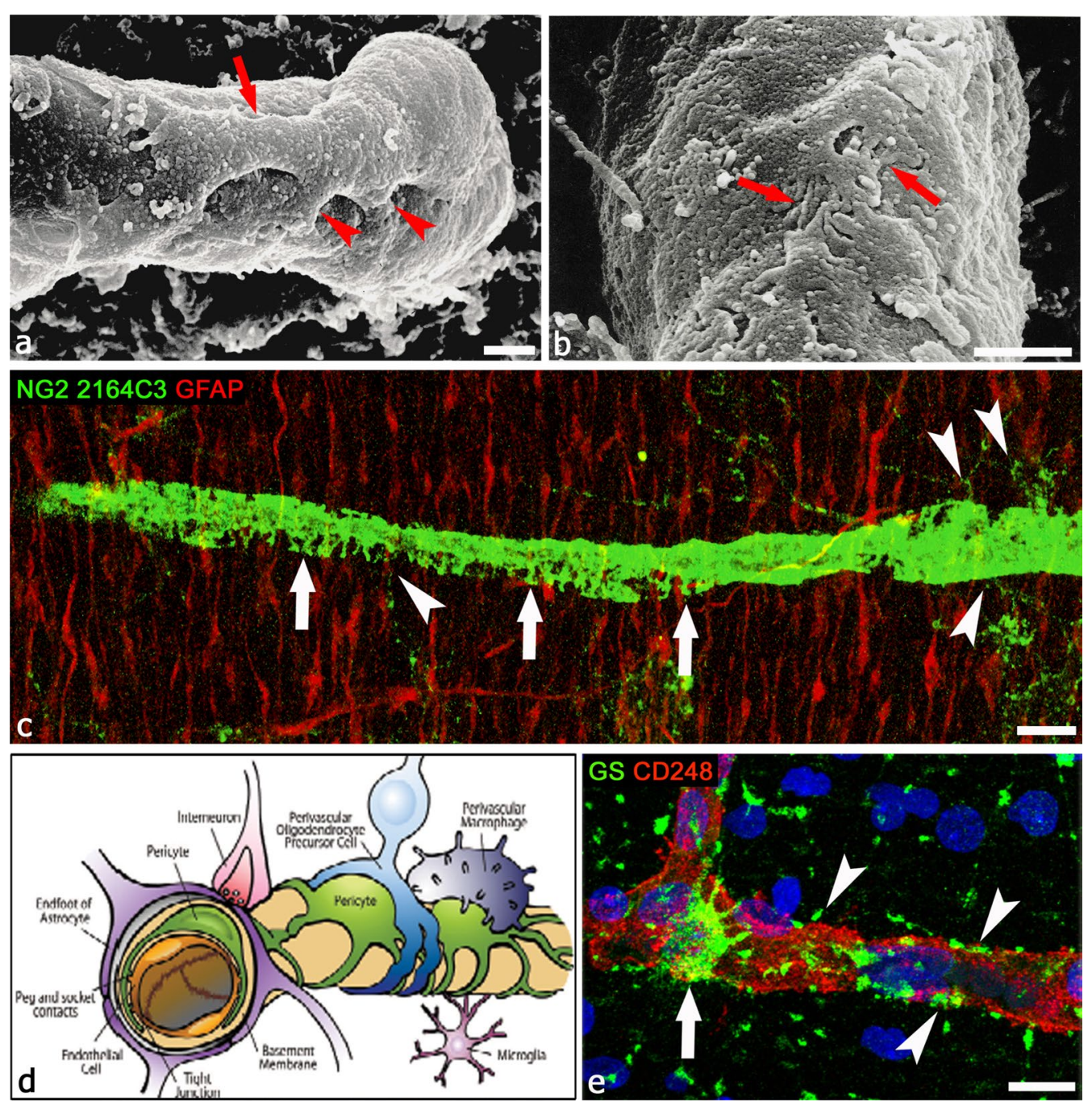

Fig. 1 Pericyte morphology and relationships within the NVU. a, b Scanning electron microscope images of 14-day-old chick embryo microvessels, showing in a primary (red arrow) and secondary (red arrowheads) pericyte processes and in $\mathbf{b}$ their highly indented and interdigitated finger-like processes (red arrows) [from [5] with permission]. c Dorsal wall of the telencephalic vesicles (forebrain, future neocortex) of an 18-week-old human fetus, GFAP (glial fibrillary acidic protein) radial glia fibers and a pericyte coverage NG2 2164C3 ${ }^{+}$, the latter shows finger-like processes (arrows); note the very fine perivascular processes of OPCs (arrowheads). $\mathbf{d}$ A schematic representation showing NVU components: ECs, PCs, perivascular astrocytes, vessel-associated microglial cells, OPCs/NG2-glia, macrophages, nerve fiber terminal [from [13] with permission]. PCs, embedded in the vessel basal lamina (here not shown) are the cells closest to the endothelium and display a variety of extensive contacts on their abluminal surface, in particular the relation with astrocytes and OPCs/NG2-glia [10]. e Astrocyte-pericyte relations are shown by glutamine synthetase (GS), confined within the astrocyte body (arrow) and in perivascular endfeet (arrowheads), most of which are in contact with CD248 ${ }^{+}$PCs rather than, directly, with ECs. Scale bars a, b $1 \mu \mathrm{m} ; \mathbf{c} 20 \mu \mathrm{m} ; \mathbf{e} 10 \mu \mathrm{m}$ 

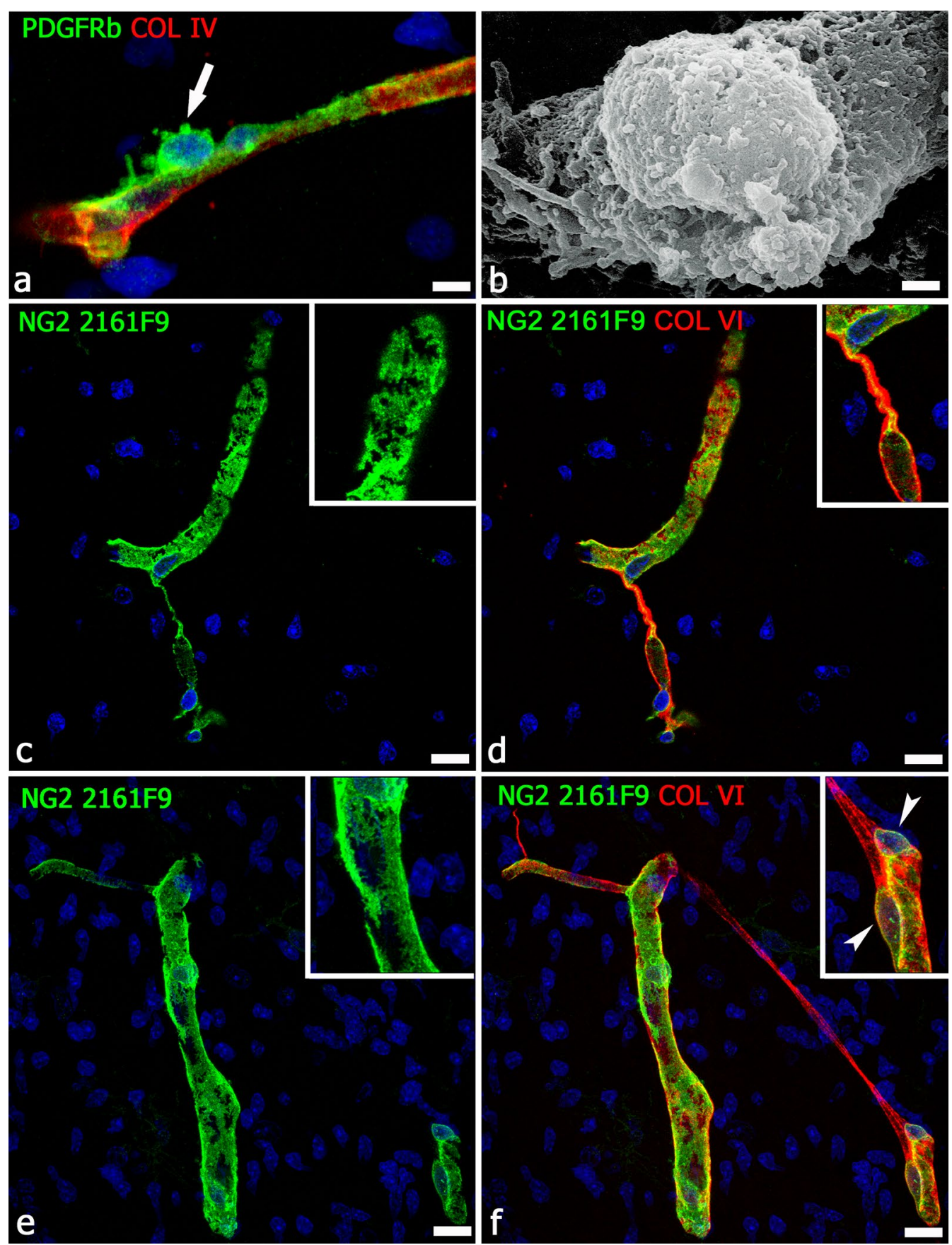

Fig. 2 Pericyte morphology and vessel basal lamina relationships. a Morphology of an activated, PDGFR- $\beta^{+}$pericyte in contact with the collagen type IV ${ }^{+}$basal lamina of a neocortex microvessel from a 22-week-old human fetus; note the abluminal bumpy surface of the PC (arrow), a detail well-depicted by the scanning electron microscopy 3D image (b; 14-day-old chick embryo) [from [5] with permission]. c, d The NG2 isoform, specifically recognized by antibody $2161 \mathrm{~F} 9$, is able to outlines the finer cell details, thus describing the real extension of the pericyte coverage (c, inset) and its relation with the collagen VI-enriched basal lamina (d); note a pericyte conduit and its collagen VI sleeve (d, inset). e, f NG2 2161 F9 immunostaining shows few large gaps in the pericyte coverage (better shown in e, inset); on the same field (f), a TNT/MT-like intervascular bridge is revealed by collagen VI staining; the inset shows two PCs close to the site of TNT/MT origin (arrowheads). a, c-f, Human telencephalon 22 wg. Scale bars $\mathbf{a} 7.5 \mu \mathrm{m} ; \mathbf{b}-\mathbf{f} 10 \mu \mathrm{m}$ 
unit (NVU) of the central nervous system (CNS), PCs develop their two-sided activity: direct communication with ECs through peg socket connections and heterotypic gap junctions, interactions through extracellular matrix molecules and soluble factors, autocrine and paracrine signaling pathways, including those involved in the astrocyte-pericyte crosstalk $[7,8]$ and in interactions with all the other vessel-associated NVU components (Fig. 1) [9-13]. The NVU is essential in CNS homeostasis, neurovascular coupling, regulation of blood flow, as well as differentiation and functional activities of the blood-brain barrier (BBB) [14, 15]. In this context, PCs accomplish direct roles in leading microvessel development, maturation, and remodeling, finally stabilizing blood vessels and contributing to the BBB function [13, 16-24]. PCs, as the cells physically closest to the brain microvascular endothelium, also display immune activities characterized by the production of immune mediators such as nitric oxide and cytokines, thus participating in neuroinflammatory processes in brain infections and neurodegenerative diseases $[13,25,26]$.

\section{Pluripotency and heterogeneity of pericytes}

The cell components pertaining to the NVU have recently been demonstrated to feature different levels of diversity, giving rise to the new concept of NVU heterogeneity [11]. Genome-wide association and RNA-seq studies have revealed morphological and functional astrocytes and microglia subtypes associated to both normal and pathological conditions [27-29]. Transcriptional profiling has highlighted the presence of different glial sub-populations [30-32], including neurotoxic, type $\mathrm{A} 1$, and neuroprotective, type A2, astrocytes associated to astrogliosis [33]. In addition, high-resolution transcriptomic analyses, together with the emergence of novel single-cell techniques and single-cell RNA sequencing, now propel studies of microglia heterogeneity, unveiling a variety of spatially and developmentally distinct microglia subtypes (for a Review see [34]. RNA-seq studies have also investigated PCs and their possible role in NVU heterogeneity [28, $35,36]$. Therefore, if it is correct to consider CNS PCs as motile, contractile cells, as proposed in Rouget's original description [1], it is also true that heterogeneity and multitasking aptitude of PCs have already been pointed out [36-44]. Different subclasses of PCs along the capillary bed and in specific developmental and pathological conditions have been identified $[13,45]$. These multiple profiles form the basis for the pericyte functional and phenotypic variety, including their differentiation along the mesenchymal lineage [46] (Table 1). PCs, as mesenchymal-like cells, are able to migrate by digesting the

Table 1 Pericyte subpopulations according to ontogeny

\begin{tabular}{|c|c|c|c|}
\hline Origin & Position & Gene expression & Roles \\
\hline $\begin{array}{l}\text { Neuroectoderm } \\
\Downarrow \\
\text { Neural crest stem cells } \\
\Downarrow \\
\text { Ectomesenchyme } \\
\Downarrow \\
\text { Ectomesenchyme-derived pericytes }\end{array}$ & $\begin{array}{l}\text { Forebrain Leptomeninges } \\
\text { Forebrain vessels } \\
\text { Retinal vessels } \\
\text { Skull, face, neck tissues } \\
\text { Truncus arteriosus } \\
\text { Mesentery (?) } \\
{[69,75-81]}\end{array}$ & $\begin{array}{l}\text { PAX3, PAX7, TFAP2A } \\
{[82]} \\
\text { FOXC1, FOXC2 [83] }\end{array}$ & $\begin{array}{l}\text { Vessel development }[76,84-87] \\
\text { Glioblastoma neo-vessels [87-94] }\end{array}$ \\
\hline $\begin{array}{l}\text { Intraembryonic Mesoderm } \\
\Downarrow \\
\text { Lateral mesoderm (mesothelium) } \\
\Downarrow \\
\text { Mesenchyme } \\
\Downarrow \\
\text { Mesenchyme-derived type } 1 \text { pericytes }\end{array}$ & $\begin{array}{l}\text { Lung } \\
\text { Heart } \\
\text { Liver } \\
\text { Gut } \\
{[69,78,81,95-98]}\end{array}$ & MIXL1, TBXT [82] & $\begin{array}{l}\text { Absence in tumor vessels [99] } \\
\text { Fibrosis, myopathies }[58,81]\end{array}$ \\
\hline $\begin{array}{l}\text { Intraembryonic mesoderm } \\
\Downarrow \\
\text { Paraxial mesoderm (sclerotome) } \\
\Downarrow \\
\text { Mesenchyme } \\
\Downarrow \\
\text { Mesenchyme-derived type } 2 \text { pericytes }\end{array}$ & $\begin{array}{l}\text { Midbrain } \\
\text { Hindbrain } \\
\text { Spinal cord } \\
{[69,76,78,100,101]}\end{array}$ & MIXL1, TBXT [82] & $\begin{array}{l}\text { Vessel development } \\
\text { Tumor neo-vessels } \\
\text { Glioma neo-vessels } \\
{[102,103]}\end{array}$ \\
\hline $\begin{array}{l}\text { Extraembryonic mesoderm } \\
\Downarrow \\
\text { Mesenchyme } \\
\Downarrow \\
\text { Yolk sac-derived myeloid progenitor } \\
\Downarrow \\
\text { Macrophage-derived pericytes }\end{array}$ & $\begin{array}{l}\text { Midbrain } \\
\text { Rostral back skin } \\
\text { Retina } \\
{[104,105]}\end{array}$ & $\begin{array}{l}\text { Kenj8, Rgs5, Dlk1, and Abcc9, } \\
\text { TGFBR2 [105] }\end{array}$ & $\begin{array}{l}\text { Vascular anastomosis [106] } \\
\text { Retinal vascular density [107] } \\
\text { Tumor angiogenesis [108] }\end{array}$ \\
\hline
\end{tabular}



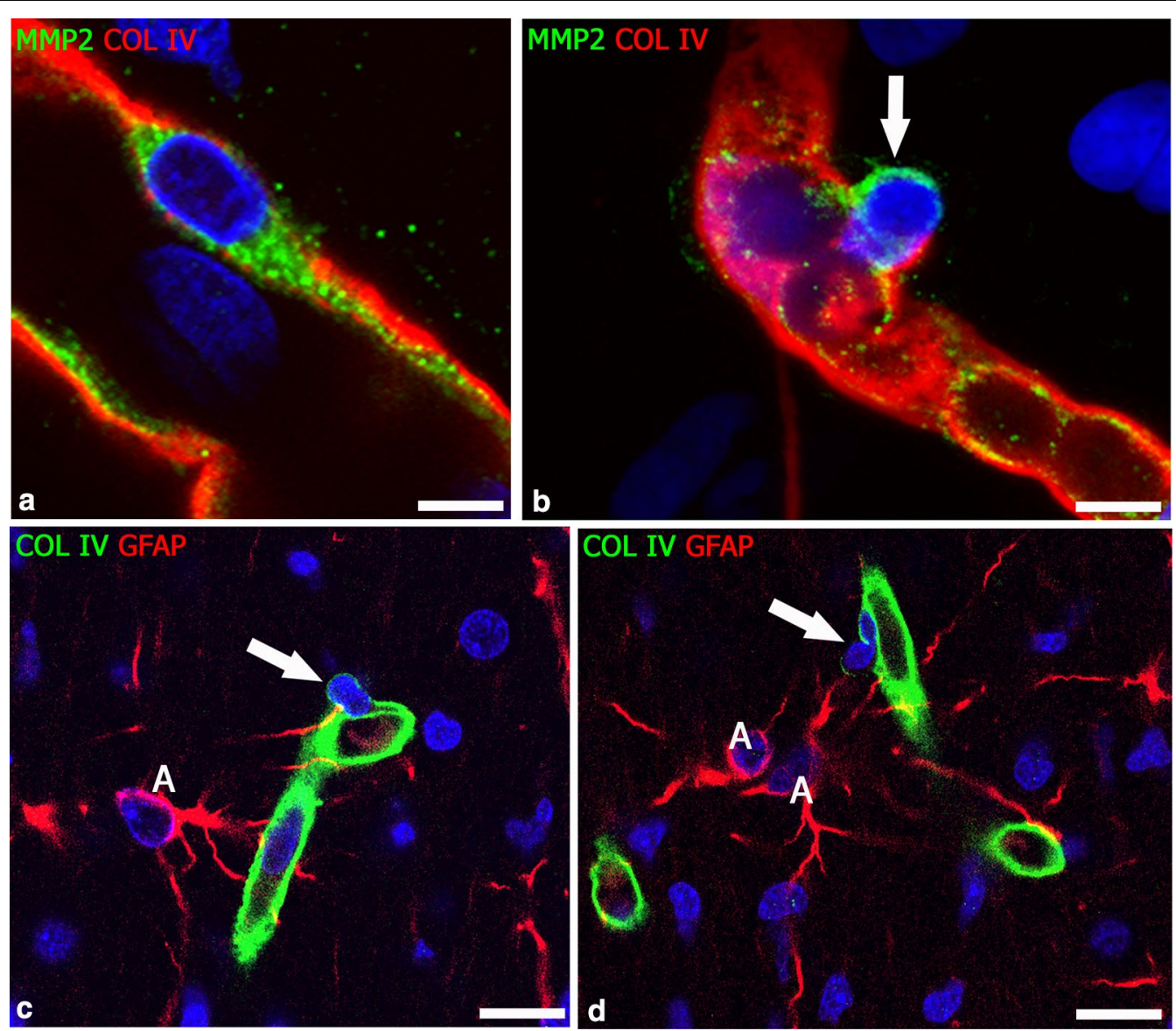

Fig. 3 Resting and migrating PCs. a An MMP2 ${ }^{+}$resting pericyte embedded in the collagen IV vessel basal lamina and $\mathbf{b}$ a migrating pericyte in the act of breaking out by releasing enzyme MMP2 (arrow). c, d Active PCs (arrow) passing through the collagen IV-enriched basal lamina; note the trace of the enzymatically attenuated collagen IV. Human telencephalon 18 weeks of gestation. A, astrocyte. Scale bars $\mathbf{a}, \mathbf{b} 7.5 \mu \mathrm{m} ; \mathbf{c}, \mathbf{d} 15 \mu \mathrm{m}$

basal lamina molecules [41, 47-49] (Fig. 3) and to differentiate into fibroblasts [50-52], smooth muscle cells [53, 54], macrophages [55, 56], osteoblasts [57], myoblasts [58], adipocytes [59], chondrocytes [60], and also into neural and glial cells comprising oligodendrocyte progenitors [42, 61-65]. A general consensus holds that PCs are cells with a high plasticity, despite two studies challenged this concept $[66,67]$. The response of PCs to specific cues in specific tissue contexts suggests that, in each of the vascular districts, PCs should be considered according to their origin and consequent morphological and functional singularities [25, 37, 68-71]. Accordingly, the variety of different pericyte subtypes $[60,72$, 73] (Table 1) and the complexity of the PCs biology and genetic profile emerge, together with the variety of the pericyte-expressed molecules studies conducted up to now and the attempts at identifying specific pan-pericyte markers $[42,68,74]$ (Table 2 ).

\section{Neural crest cells and head morphogenesis}

Wilhelm His, observing the CNS development in neurula-stage chick embryos, was the first to describe the appearance of neural crest cells (NCCs) (Zwischenstrang) as cellular elements derived, but distinct, from the neuroectodermal cells that form the neuroepithelium of the neural tube [236]. Pioneering studies in fish demonstrated the capacity of these (neuro)ectodermal cells to colonize the embryo head [237]. However, despite of these early observations, the existence, distribution, and fate of the NCCs remained largely ignored by embryologists for decades, and then became the subject of active controversies. NCCs, soon after their detachment from the neuroectoderm fold lips, undergo an epithelial-tomesenchymal transition, becoming hardly distinguishable, along their migratory pathways and inside the colonized tissues and organs, from typical mesenchymal cells of mesodermal origin. It was an embryologist, Julia Platt [238], who first recognized the head mesenchyme 
Table 2 Markers of pericytes expressed in healthy and diseased CNS (with BBB dysfunction)

\begin{tabular}{|c|c|c|}
\hline Pericyte marker & Healthy CNS & Diseased CNS \\
\hline Neuron-glial antigen 2 (NG2) & Development $[10,40,80,84,88,109-112]$ & $\begin{array}{l}\text { Dementia [113] } \\
\text { Healing wounds [114] } \\
\text { Neurofibromatosis [115]. } \\
\text { Neuroinflammation }[116,117] \\
\text { Tumor neovasculature }[10,87,88,114,118-122] . \\
\text { Traumatic injury }[123,124]\end{array}$ \\
\hline NG2 isoforms & Development $[88,125]$ & $\begin{array}{l}\text { Glioblastoma [88, 126] } \\
\text { Ullrich's congenital muscular dystrophy [125] }\end{array}$ \\
\hline $\begin{array}{l}\text { Platelet derived growth factor receptor beta } \\
\text { (PDGFR } \beta \text { ) }\end{array}$ & $\begin{array}{l}\text { Development }[84,127,128] \\
\text { Adult }[10,18,40,70,108,110,129-132]\end{array}$ & $\begin{array}{l}\text { Alzheimer's disease }[129,133,134] \\
\text { Amyotrophic lateral sclerosis }[135,136] \\
\text { Angiopathies }[132,137-142] \\
\text { Neuroinflammation }[10,123,143,144] \\
\text { Tumor neovasculature }[108,145]\end{array}$ \\
\hline Alanyl aminopeptidase (CD13) & Adult $[10,35,70,74,128,131,146-149]$ & $\begin{array}{l}\text { Neuroinflammation [150] } \\
\text { Stroke [151] }\end{array}$ \\
\hline Vimentin (VIM) & Adult $[39,131,152,153]$ & Angiopathies [154-156] \\
\hline Regulator of G protein signaling 5 (RGS5) & Development [157-161] & $\begin{array}{l}\text { Huntington's disease [162] } \\
\text { Stroke [163-166] }\end{array}$ \\
\hline Smooth Muscle a-Actin ( $a$-SMA) & $\begin{array}{l}\text { Adult (pre- and post-capillary pericytes) [70, } \\
128,131,167-172]\end{array}$ & $\begin{array}{l}\text { Retinal angiopathy [170] } \\
\text { Familial form of Alzheimer's disease [173] }\end{array}$ \\
\hline Vascular endothelial growth factor (VEFG) & Development $[174,175]$ & $\begin{array}{l}\text { Angiopathies }[176,177] \\
\text { Neurotoxicity }[178]\end{array}$ \\
\hline CXCR4 & Development [179-181] & $\begin{array}{l}\text { Glioma [182, 183] } \\
\text { Neuroinflammation [184] }\end{array}$ \\
\hline Toll-like receptor 4 (TLR4) & Adult (transcriptome analysis) [185] & Stroke $[186,187]$ \\
\hline $\begin{array}{l}\text { ATP binding cassette subfamily } C \text { member } 9 \\
\text { (ABCC9) }\end{array}$ & Adult $[131,188]$ & Aging [189] \\
\hline Melanoma Cell Adhesion Molecule (CD146) & Development $[74,87,190,191]$ & Glioblastoma [87] \\
\hline Vascular cell adhesion molecule-1 (VCAM-1) & FACS [192] & $\begin{array}{l}\text { Neuroinflammation [56] } \\
\text { Tumorigenesis [193] }\end{array}$ \\
\hline Intercellular adhesion molecule-1 (ICAM-1) & $\begin{array}{l}\text { FACS [192] } \\
\text { Cell cultures [56] }\end{array}$ & Neuroinflammation $[56,194]$ \\
\hline 3G5-defined ganglioside & Adult [195] & Retinopathies $[196,197]$ \\
\hline Angiopoietin 1 and 2 and Tie2 receptor & Development [198-201] & $\begin{array}{l}\text { Diabetic retinopathy [202] } \\
\text { Neurotoxicity }[175] \\
\text { Stroke }[203,204]\end{array}$ \\
\hline Leptin receptor (LepRb) & Development [205] & Neuroinflammation [206] \\
\hline Endosialin (CD248) & Development [84, 207-209] & Glioma $[88,208,209]$ \\
\hline $\begin{array}{l}\text { Sphingosine-1-phosphate receptor } 2 \text { and } 3 \text { (S1PR2 } \\
\text { and 3) }\end{array}$ & Adult $[198,210,211]$ & $\begin{array}{l}\text { Stroke }[211,212] \\
\text { Traumatic injury [213] }\end{array}$ \\
\hline Transforming growth factor $\beta$ (TGF $\beta$ ) & $\begin{array}{l}\text { Adult [198] } \\
\text { Cell cultures [171, 214] }\end{array}$ & Neuroinflammation $[10,215,216]$ \\
\hline Angiotensin 1 and 2 receptors (AT1 and AT2) & Cell cultures $[179,217,218]$ & Diabetic retinopathy $[219,220]$ \\
\hline $\begin{array}{l}\text { ATP-gated Purinergic } 2 X \text { receptor cation channel } \\
\text { (P2X7R) }\end{array}$ & Adult [221] & $\begin{array}{l}\text { Diabetic retinopathy }[222] \\
\text { Neuroinflammation }[221,223]\end{array}$ \\
\hline Zic1 & Development [83] & \\
\hline Potassium inwardly-rectifying channel (Kir6.1) & Adult $[131,188,224]$ & \\
\hline Delta Like Non-Canonical Notch Ligand 1 (DLK1) & Adult (microarray analysis) [188] & \\
\hline Vitronectin (VTN) & Development $[110,225]$ & \\
\hline $\begin{array}{l}\text { Interferon-induced transmembrane protein } \\
1 \text { (Ifitm-1) }\end{array}$ & Development (transcriptome analysis) [110] & \\
\hline Myosin light chain phosphatase (MLCP) & Cell culture [226] & \\
\hline Fluoro-Nissl dye NeuroTrace 500/525 & Adult [227] & \\
\hline Forkhead transcription factor C1 (FoxfC 1) & Development [83] & \\
\hline $\begin{array}{l}\text { Interferon-induced transmembrane protein } \\
1 \text { (Ifitm-1) }\end{array}$ & Development (transcriptome analysis) [110] & \\
\hline
\end{tabular}


Table 2 (continued)

\begin{tabular}{lll}
\hline Pericyte marker & Healthy CNS & Diseased CNS \\
\hline Connexin 30 (Cx30) & Adult [228] & \\
P-type ATPase (Atp13a5gene) & Adult (transcriptome analysis) [131] & \\
Basic fibroblast growth factor (bFGF) & & Stroke [229] \\
Sox2 and Klf4 & Stroke [230] \\
protein encoded by the NOTCH3 gene & CADASIL angiopathy [231-234] \\
Bone morphogenetic protein 4 & Alzheimer's disease, angiopathies [235] \\
\hline
\end{tabular}

as derived from NCCs and coined the term 'mesectoderm' to denote the mesenchyme of neuroectodermal origin (now known as 'ectomesenchyme'), distinct from the 'mesentoderm', a term that indicated the mesenchyme which originates from the mesodermal germ layer (now simply 'mesenchyme'). More recently, after more than half a century from these observations, the role of NCCs during head morphogenesis began to be unveiled by fate-mapping experiments [239]. Subsequently, embryoto-embryo transplant studies in the chick-quail chimera experimental models made it possible to define the NCCs as a pluripotent, 'stem', embryonic cell population (neural crest stem cells, NCSCs), able to develop into a large variety of tissues, including cartilages, membranous bones, cartilaginous bones and other connective components, such as dermis and tendons, and also skeletal and visceral muscles, during skull (neurocranium) and face- (splanchnocranium) and neck-branchial regions development [240-244]. In addition, the NCSC-derived ectomesenchyme gives origin to the leptomeninges, including the forebrain leptomeninges, and is necessary for neuroepithelium survival and vascularization [239, 240, 245] (Table 1).

\section{Neural crest stem cell-derived pericytes}

Little is known about the exact identity of pericyte ancestors within developing tissues, and distinct developmental sources have been demonstrated, highlighting that the embryonic origin of PCs differs among tissues and organs $[69,246,247]$. Several studies using lineage tracing methods indicate that PCs in part of the cephalic region and thymus have an ectomesenchyme origin [248-252], while in the lung, heart, liver and gut, PCs derive from the mesothelium. Thus, they have a lateral mesoderm, epitheliallike, mesenchymal origin [69, 78, 95-98]. In most other organs, PCs derive from the paraxial mesoderm, specifically the sclerotome compartment, so again they have a mesenchyme origin $[69,76,78,100]$ (Table 1).

\section{Neural crest stem cell-derived forebrain pericytes}

During embryonic neurogenesis, NCSCs are concentrated at the cranial and ventral secondary encephalic vesicles (telencephalon and diencephalon) of the forebrain. In this region, unlike in the remaining parts of the brain (midbrain, hindbrain) [253, 254], PCs, hereafter named forebrain PCs, derive entirely from NCSCs, thus they represent a subset of PCs with a specific ontogeny and are distally sharply delimited by the midbrain [69, 75-80]. In the anterior/ventral head regions, NCSCs are initially present in the ectomesenchymal layer comprised between the surface ectoderm and the developing CNS, where they differentiate into PCs and become associated with mesoderm-derived endothelial precursors that express VEGFR2 (vascular endothelial growth factor receptor 2) [76]. The resulting vascular plexus then ramifies and vascularizes the forebrain leptomeninges (arachnoid mater and pia mater), retinal choroids, and facial structures. Therefore, as already described, NCSCs participate in the constitution of the forebrain meninges $[239,240]$, which enclose the deeper, pial capillary network, necessary for later vascularization of the brain. Passing through the meninges, capillaries with PCs of ectomesenchyme origin supply the forebrain, while capillaries with PCs of mesenchyme origin supply the mesencephalon, the rhombencephalon and the spinal cord. An intriguing aspect of PCs origin and heterogeneity is the demonstration of PCs localized in the mouse embryonic rostral back skin, an ectodermal derivative, and some PCs in the midbrain, a neuroectodermal derivative, sharing the same origin with myeloid progenitors; these cells differentiate into PCs under the TGF- $\beta$ (transforming growth factor- $\beta$ ) signaling control $[104,105]$.

Generation of pericytes by hiPSC-derived neural crest cells Mesoderm-derived PCs and NCC-derived PCs can be obtained from induced pluripotent stem cell (iPSC) [77, 82, 255]. A recent study [82], starting from human iPSC obtained from healthy and AD patients (human iPSC; hiPSC), developed two differentiation-inducing protocols serving to generate both mesoderm-derived (mesenchymal) PCs and NCC-derived (ectomesenchymal) PCs. Firstly, hiPSCs were grown in either a mesodermal induction medium or in neural crest induction medium, in order to generate mesodermal cells and 
NCCs, respectively. Following induction, cells were passaged and maintained in pericytes medium, which stimulates pericytes differentiation. The pericyte identity of both mesoderm- and NCC-derived PCs was demonstrated by the expression of pericyte cell-surface markers, PDGFR- $\beta$ (platelet-derived growth factor receptor- $\beta$ ), NG2 (neuron-glial antigen 2), CD13 and CD146, and of brain pericyte-specific genes, vitronectin and the forkhead transcription factors, FOXF2 and FOXC1. Interestingly, FOXF2, which is expressed by NCCs during development, was primarily expressed by NCC-derived PCs, while WNT signaling seemed to be specifically associated to pericyte development through the NCC pathway. Reliable methods for engineering brain-specific subpopulations of PCs from hiPSCs are a promising improvement of in vitro studies on both barriergenesis and angiogenesis. However, the main limitation for iPSCs derived PCs and others NVU cell components remains the lack of the important contribution of cell-cell contact and fluid shear stress and, moreover, the maturation of these cells to the adult brain PCs. The roles of major signaling pathways on them and their secretome have not been studied yet [256]. Nonetheless nowadays stem cell-based BBB models represent the main tool for neurodegenerative, neuroinflammatory and brain tumor disease modeling where PCs may play important underestimated roles.

\section{Human neocortex and the developing NVU}

In the entire CNS, within the NVU, PCs are heavily involved in maintaining tissue homeostasis, vessel stability, and integrity of BBB cellular and molecular mechanisms [257-270]. Nonetheless, specific properties have been observed for NCSC-derived PCs, that contribute to the vascularization of forebrain that will develop the telencephalon dorsal wall (future neocortex), where the origin of forebrain PCs from NCSCs seems to entail additional biological functions, involved in both angiogenesis and barriergenesis [271, 272]. In our studies on human telencephalon development and vascularization, we have relied on the detection of NG2, an integral membrane chondroitin sulphate proteoglycan encoded by the Cspg4 gene pericyte marker (Fig. 2). NG2 was firstly identified as an important neural cell surface antigen by Stallcup and Cohn [273] and its expression by active, immature PCs and proliferating oligodendrocyte precursor cells (OPCs) was demonstrated [274, 275]. The large juxtamembrane extracellular domain (D3) of NG2 mediates several cell-cell and cell-matrix interactions, including a fundamental role in endothelial cell adhesion and spreading (for a comprehensive review please see Nishiyama et al. [276]).

\section{The forebrain pericytes leading role in human cerebral cortex vascularization}

In humans, a large part of organogenesis (early ontogenesis) takes place during the embryonic period, that is limited to the first 8 weeks of embryonic development, while ontogenesis will continue during the subsequent fetal development. At the 9th week of gestation [277, 278], the telencephalic vesicles are already surrounded by a perineuronal vascular plexus of a composite origin: mesenchyme-derived ECs and ectomesenchyme-derived PCs [76], in fact, NCCs give origin to the PCs, although not to the ECs [240, 279]. When the cerebral cortex starts to form, soon after the pre-plate stage (9-9.5 weeks of gestation), vessel sprouts originate from the perineural vascular plexus and, guided by a VEGF gradient [127, 280], radially invade the nervous wall, elongate, and start to branch at their distal ends [281-284] (Fig. 4). Therefore, NCC-derived PCs associated with these parenchymal microvessels, including those associated to the vascular bed of the choroid plexuses [76], are already present at the very beginning of brain vascularization. In human developing cortex, $\mathrm{NG}^{+}$forebrain PCs are promptly detectable, together with early NVU radial glia components $[84,85]$ and with EC structural and functional hallmarks of BBB differentiation (Fig. 4). In fact, in humans the process of cerebral cortex vascularization seems to proceed in parallel with the appearance of an endothelial $\mathrm{BBB}$ phenotype and barrier devices, such as endothelial tight junctions [285], metabolic transporters [286], and efflux transporters [287]. This distinctive feature highlights the vital role played by the BBB also during CNS development, as recently confirmed by an in vivo study on transgenic zebrafish lines [288]. Human forebrain PCs that establish tight relations with ECs during the earliest stages of vessel growth [84], and contribute to vessel stability [51] and BBB function [40], also appear to play important roles during angiogenesis and vessel branching. In fact, forebrain PCs, identified by NG2 and CD146, have been observed at the leading edge of growing vessels [289], where these cells are able to raise tunnelling nanotubes (TNTs) and microtubes (MTs) and, like ECs, are also seen to form leading sprout-like structures (Fig. 5) [87]. Pro-angiogenic PCs, surrounded by a collagen type IV- and type VI-enriched basal lamina, appeared always in contact with radial glia cells (Fig. 6) [87]. Pericyte MTs have been described as EC-free conduits [89], then able to recruit ECs according to a process that seems to reverse the classical EC/pericyte interplay and that has been suggested as an alternative mode of vessel growth [84] (Fig. 7). These data, diverging from the classical angiogenic model consisting of endothelial sprouting and pericyte recruitment events [69, 127, 290], should be considered to reveal a direct angiogenic activity of PCs 

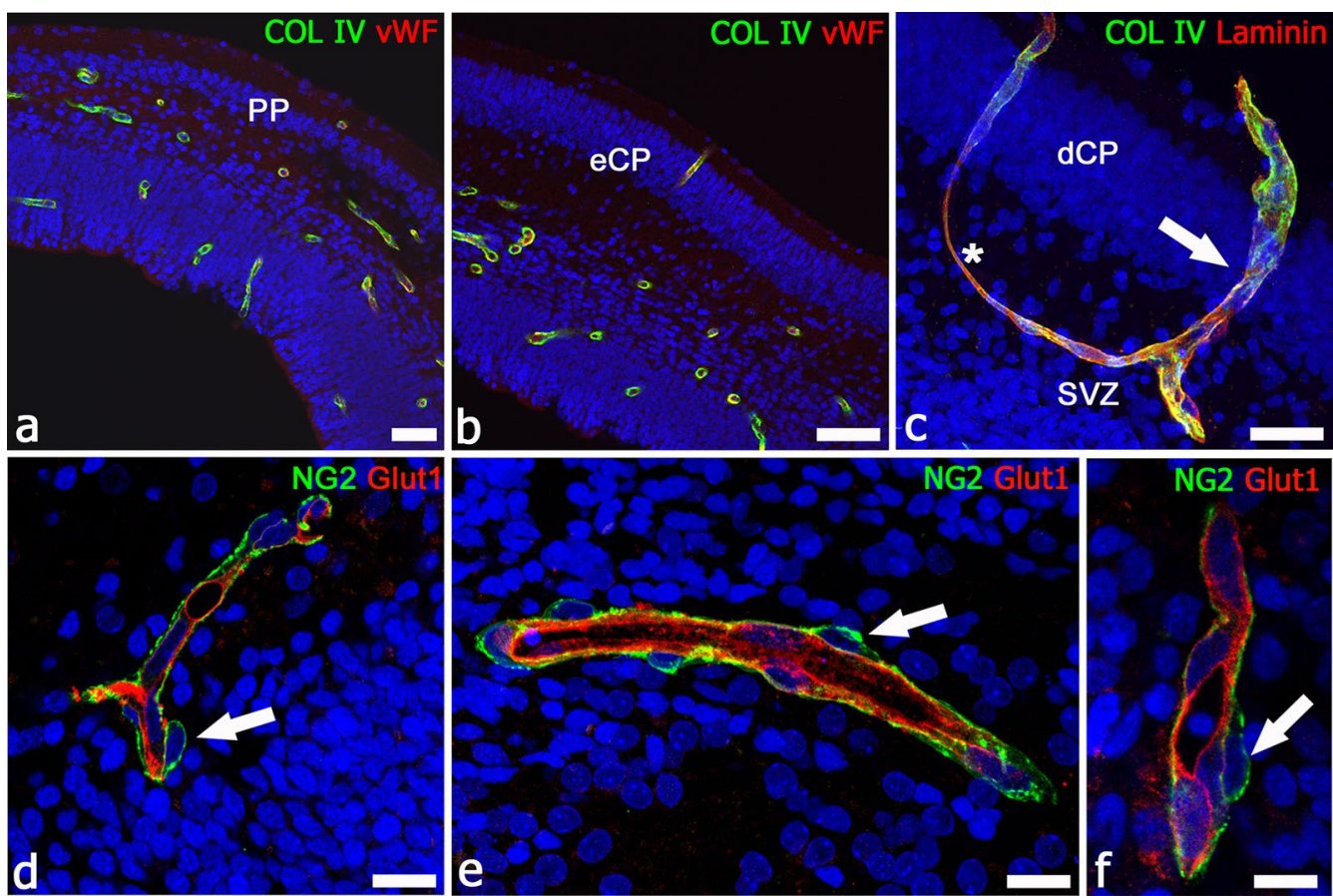

Fig. 4 First steps in human dorsal telencephalon vascularization. a-c Sequence of cerebral cortex formation and vascularization at 9/9.5 weeks of gestation (a, pre-plate; PP), 10 weeks of gestation (b, early cortical plate; eCP), and 12 weeks of gestation (c, developing cortical plate; dCP): the newly penetrated microvessels are lined by von Willebrand factor (VWF)-reactive ECs and surrounded by collagen IV (a, b) and by collagen IV and laminin (c); note in c a penetrating microvessel (arrow) that branches in the subventricular zone (SVZ) and forms a loop-like anastomosis (asterisk). d-f During these early phases of cerebral cortex vascularization, ECs express the BBB-specific transporter Glut1 and are enwrapped by a continuous layer of $\mathrm{NG}^{+} \mathrm{PCs}$ (arrow). d-f Human telencephalon 12 weeks of gestation. Scale bars $\mathbf{a} 40 \mu \mathrm{m} ; \mathbf{b} 10 \mu \mathrm{m}$

[291] and offer a possible 'additional' perspective on angiogenic mechanisms (Additional file 1: Figure S1). Pericyte TNT/MT-like structures, and a direct involvement of these cells in early angiogenesis, were firstly reported by Nehls et al. [292], who detected cord-like structures in whole-mount preparations of rat mesentery, composed solely of PCs at the sprouting front. The PCs lay at and in front of the advancing tips of endothelial sprouts and also bridged the gap between the leading edges of opposing endothelial sprouts. These observations mirror the description of pericyte TNT/MT as guiding structures aiding the outgrowth of ECs during human cerebral cortex vascularization [87]. Previous studies postulate an alternative contribution of $\mathrm{PCs}$ to neovascularization, describing endothelium-free pericyte tubes and segments of growing sprouts formed by PCs in both normally developing microvasculature of mouse retina and tumor vascularization (including melanomas and gliomas) [89], in murine tumor models [86], in subcutaneous matrigel plug assays, and in adult mouse cornea [293]. Interestingly, tubular structures, observed in tumors and denoted tumor microtubes (TMs), have been considered closely related to TNTs/MTs, although they possibly also have other functions [294]. It is therefore conceivable that conduit-forming PCs may be able to promote a selfregulated process of endothelization/lumenalization, through trans-basal membrane interactions [52], including the processes more directly mediated by NG2. In fact, ECs adhere to and spread on NG2-coated surfaces, and NG2 stimulates the migration of ECs and promotes corneal angiogenesis [295].

\section{The supportive paracrine role of pericytes}

Besides the stabilizing role exerted by PCs on ECs $[52,158]$, there is an active angiogenic effect of PCs in secreting proregenerative molecules in response to PDGF-B [295, 296]. Of particular note is VEGF, which has been immunolocalized in PCs during human cerebral cortex development [174] and is released by these cells in in vitro models [175, 296, 297]. In a mathematical, biomimetic 3D angiogenesis model, it has been demonstrated that PCs intervene in the VEGF/TNF- $\alpha$ (tumor necrosis factor- $\alpha$ ) proangiogenic/ antiangiogenic interplay, promoting a proangiogenic effect of TNF- $\alpha$, thus allowing complete VEGF-induced sprout formation, elongation, and lumenalization, and also ensuring that the efficacy of the reverted TNF- $\alpha$ effect is proportional to the extension of the pericyte coverage. In fact, TNF- $\alpha$ activity is fully inhibitory with a very low pericyte 

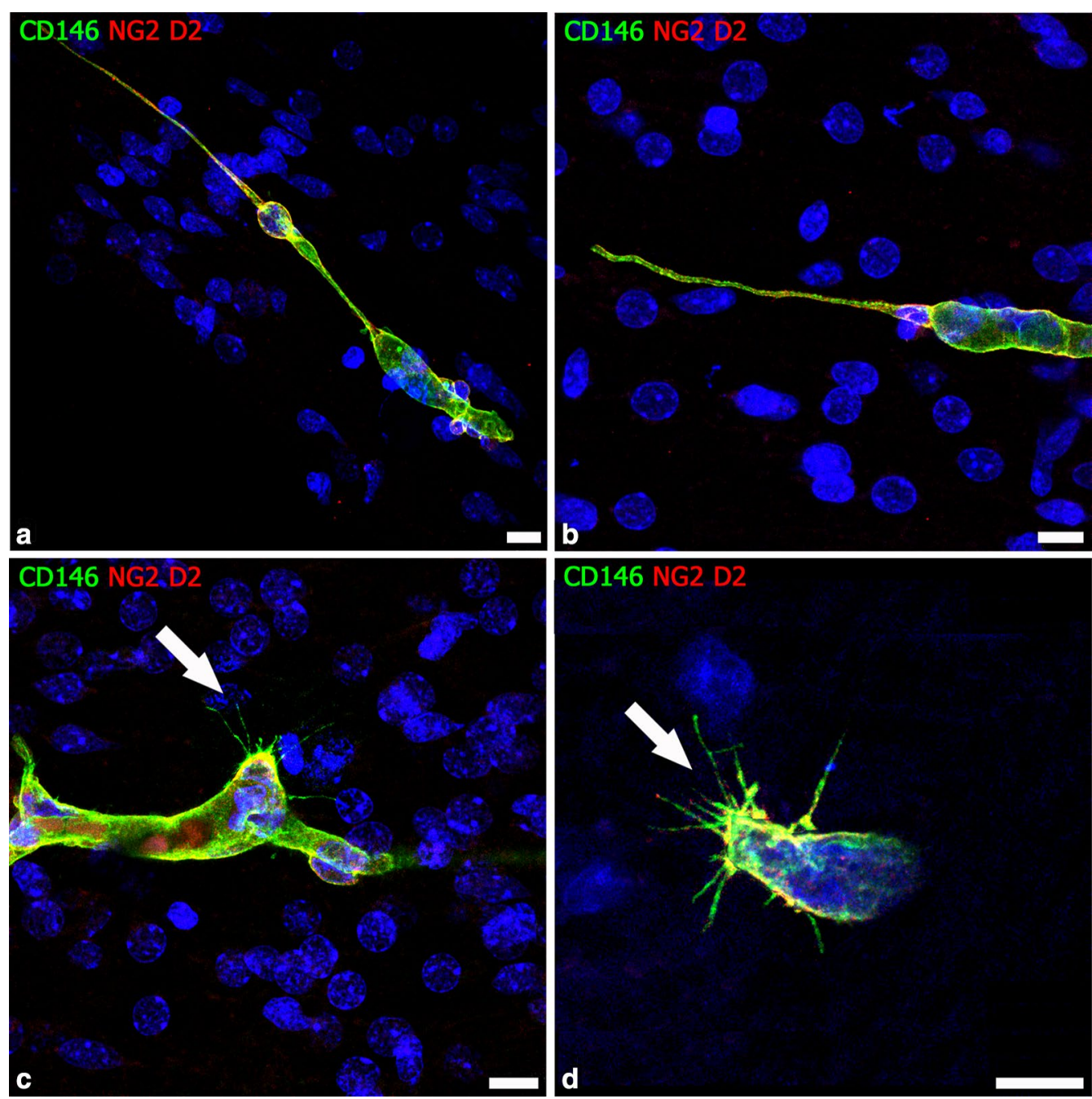

Fig. 5 Pericyte-derived leading structures during human cerebral cortex vascularization. $\mathbf{a}$, b Forebrain PCs, revealed by colocalization of NG2 and CD146, form the leading tip of cerebral cortex growing microvessels and give rise to TNT-like (a) and MT-like (b) structures. c, d CD146 staining unveils the filopodial processes of $\mathrm{NG}^{+} / \mathrm{CD}_{146}{ }^{+}$sprouting PCs (arrow). (a from [87] with permission). Human telencephalon 22 weeks of gestation. Scale bars a-c $10 \mu \mathrm{m} ; \mathbf{d} 7.5 \mu \mathrm{m}$

coverage, and switches sharply to strongly proangiogenic in the presence of a uniform pericyte coverage [298]. In the above-cited study on mesoderm- and NCC-derived PCs obtained from induced pluripotent stem cells (hiPSCs) [82], it was demonstrated that both mesoderm- and NCCderived PCs are able to induce the formation of endothelial lumenalized tube-like structures and that the activity of NCC-derived PCs was significantly more effective (Additional file 2: Figure S2).

\section{The forebrain pericytes leading role in glioblastoma neo-angiogenesis}

In our hypothesis, forebrain PCs may display a unique angiogenic aptitude as compared to the PCs of mesodermal origin, found in other regions of the CNS. Exploratory studies of pericyte-endothelial relationships during human fetal brain vascularization revealed an intimate interplay between the ECs and the leading activity of forebrain PCs in vessel sprouting events [84, 289]. Notably, glioblastoma multiforme (GBM) is the most highly vascularized brain neoplasm, it is characterized by very active and diverse angiogenic mechanisms, and by a tumor microvascular architecture heterogeneity, including tumoral cell channels (vessel mimicry), intussusceptive vessels, and glomeruloid vessels [299, 300]. In GBM, we have observed the presence of several glomeruloid vessels, where NG2+/CD248+ PCs, expressing a variety of NG2 molecular forms, proliferate and 

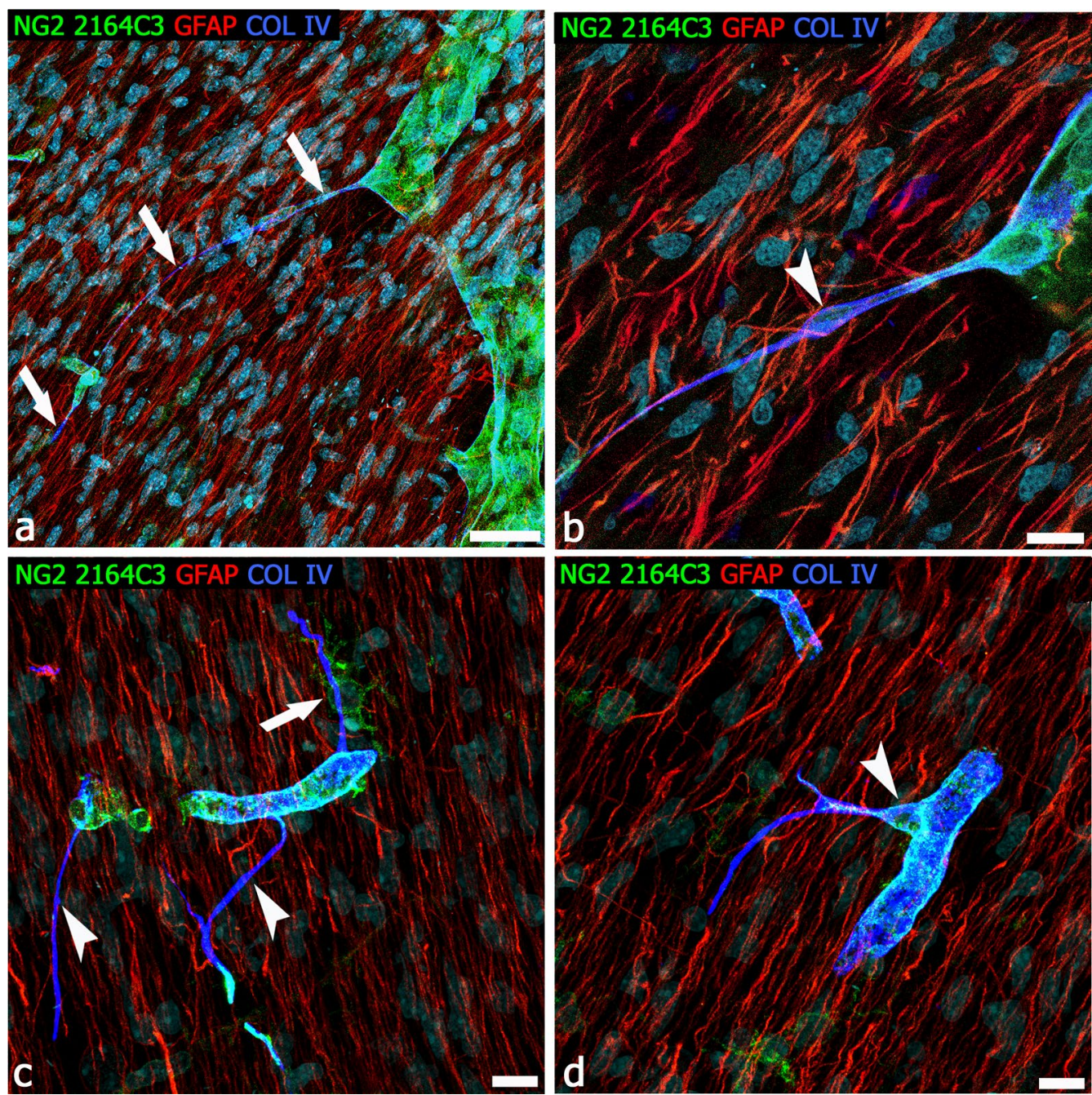

Fig. 6 Radial glia/pericyte TNT relationships in the human developing cerebral cortex. a, b Triple staining with antibody NG2 2164C3, GFAP, and collagen IV reveals a very long pericyte TNT and the accompanying collagen IV basal lamina (a, arrows), enlarged on a single optical plane in $\mathbf{b}$; note a TNT conveyed nucleus (arrowhead) and the extensive relations with GFAP ${ }^{+}$radial glia fibers. c Multiple NG2 ${ }^{+}$collagen IV ${ }^{+}$TNTs (arrowheads) arise from the same parental vessel, one of which receives multiple contacts from a perivascular NG2+ OPC (arrow). $\mathbf{d}$ A ramified TNT arises from the pericyte body (arrowhead). Human telencephalon 22 weeks of gestation. Scale bars a $20 \mu \mathrm{m} ; \mathbf{b}-\mathbf{d} 10 \mu \mathrm{m}$

form a multilayered shell [88]. Hyperplastic PCs, whose rate of proliferation increases with the glioma grade, but not ECs, that appear confined to the monolayer lining cells, have been described as the main feature of higher grade glioma vessels, together with pericyte tubular or cord clusters [301]. It has been suggested that tumoral PCs originate endothelium-free vessel-like structures, that may play important, active and direct roles in tumor neoangiogenesis [87-92] (Fig. 8). An additional possible rationale for the demonstrated improvement of chemotherapy efficiency, in xenograft mouse glioma models after GBM-derived pericyte targeting [94], has given rise to the intriguing idea of identifying molecular markers for TNTs/MTs/TMs so as to pharmacologically disconnect the TNT/MT/TM communication networks [302]. This idea hypothesized the pericyte TNT/MT/TM-supported and pericyte-guided tumor angiogenesis roles in the control of cancer onset and progression.

\section{What do forebrain, retinal, mesenteric, and tumoral pericytes have in common?}

NCSC-derived ectomesenchyme has been demonstrated to have a trophic effect on the early forebrain; in fact, the removal of the posterior diencephalic and mesencephalic neural folds produces massive cell death preceding the forebrain normal period of vascularisation [303]. When 

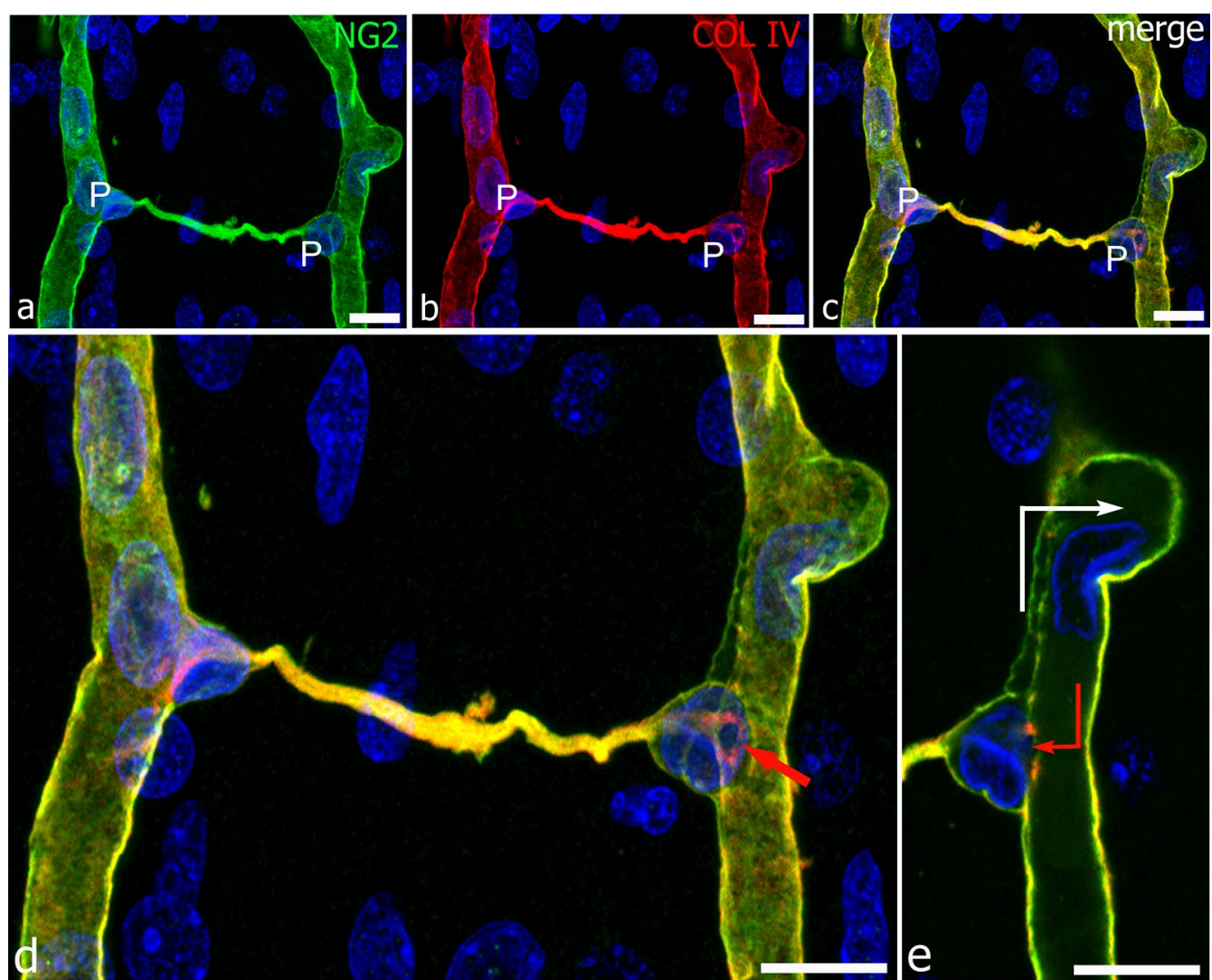

Fig. 7 A pericyte conduit between facing radial vessels of the developing human cerebral cortex. a-c Two pericytes (P) are located at the opposite terminals of an $\mathrm{NG}_{2}{ }^{+}$collagen $\mathrm{IV}^{+}$bridging conduit; as often observed, their nucleus marks the point of TNT/MT origin. $\mathbf{d}$ The enlargement of the merged image in c reveals further details and shows that in both the PCs, the nucleus is bent over on itself, describing a phrygian hat-like shape, so leaving an opening directly communicating with the lumen of the parental vessel; the entrance to the 'tunnel' is revealed by the collagen IV-enriched endothelial layer of the vessel basal lamina (red arrow). This critical passage is better shown in the single optical plane from the z-stack (e, red arrow); note the nucleus of an EC (white arrow) engaged through a collateral root. Human telencephalon 22 weeks of gestation. Scale bars a-e $25 \mu \mathrm{m}$

NCSCs migrate from the mesencephalic regions (midbrain) towards the forebrain, the forebrain is formed by a cranial telencephalon ("end-brain") and a caudal diencephalon ("between brain"), which gives rise to optic cups. The latter is also surrounded by a layer of mesenchyme derived from NCCs. The wall of the optic cup is continuous with the neuroectoderm and will form the pigmented epithelium of the neural retina, while NCCs contribute to the stroma of the cornea, the ciliary and iris muscles, fibrous sclera, and vascular choroid layers, whose angioblasts are, however, formed by the mesoderm. It therefore seems conceivable that retinal capillaries have a composite origin, namely mesoderm-derived ECs and ectomesenchyme-derived PCs, and a PC-driven angiogenesis as described in the human cerebral cortex $[86,89,304]$.
Nehls et al. [292] were the first to challenge the dogma of PCs as cells secondarily recruited to stabilize the newly-formed microvessel, and without any obvious role during the initial phase of vessel sprouting. In their study they investigated the angiogenic reaction of PCs, after intraperitoneal application of angiogenic stimuli utilizing whole-mount preparations of rat mesenteries and desmin immunocytochemistry. Their results show that PCs are involved in the earliest stages of capillary sprouting (see above) [292]. In this regard, and according to Sehgal [305], the enteric nervous system (ENS) predominantly originates from the vagal NCCs, located in an area between the brain and the spinal cord (post-otic hindbrain). From this area, NCCs migrate along dorsolateral and ventromedial pathways, through which this latter group enter the proximal foregut to give rise to the ENS. 

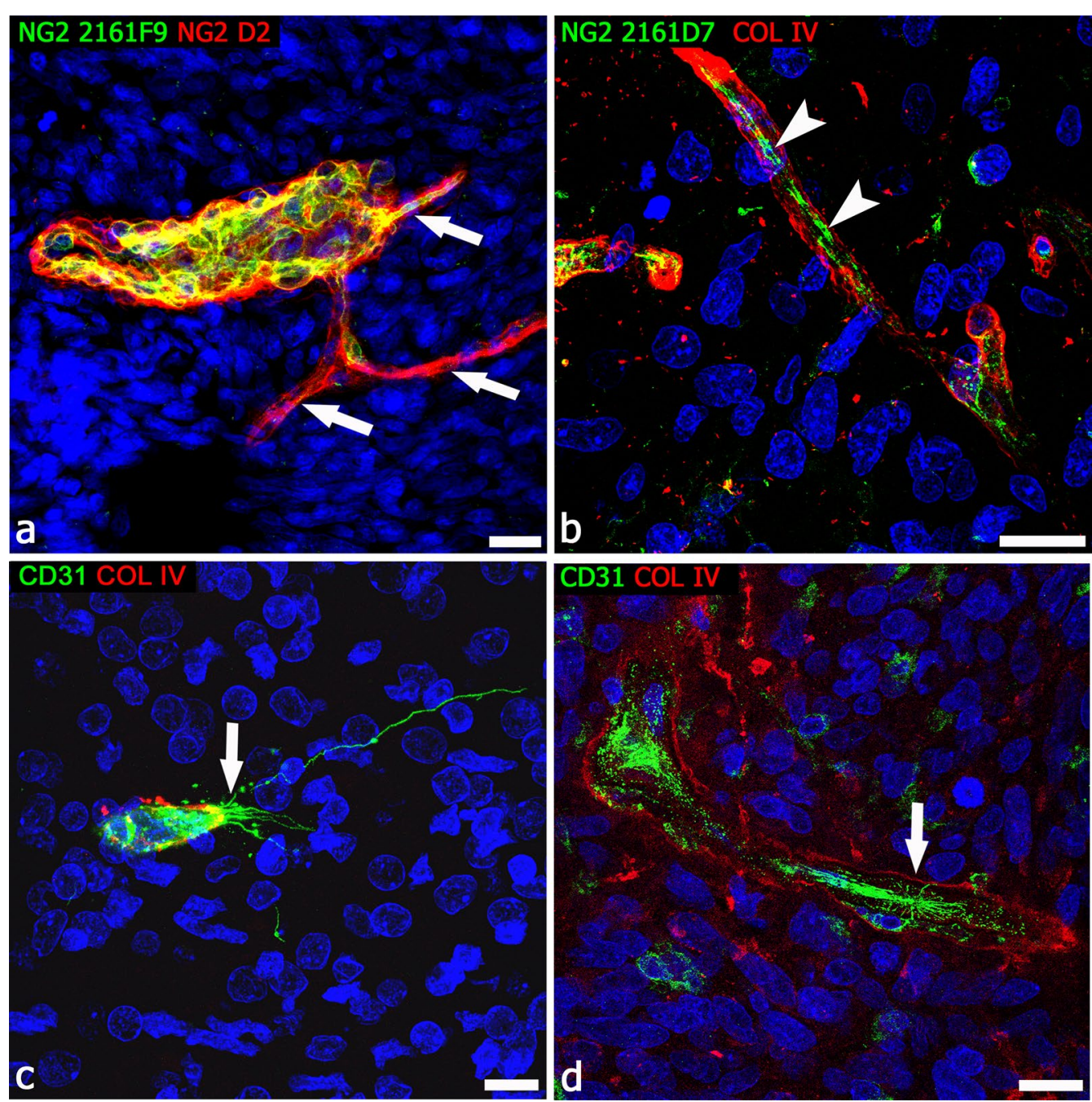

Fig. 8 Example of alternative modes of tumor vessel growth in human GBM. a, b Multiple, EC-free pericyte conduits arise from a tumor vessel characterized by multilayers of PCs labeled by different NG2 isoforms (a, arrows) and an NG2 ${ }^{+}$pericyte MT surrounded by the collagen IV basal lamina (b, arrowheads). c A typical vessel sprout observed during cerebral cortex vascularization in a human fetus at 22 weeks of gestation; the $\mathrm{CD}_{3}{ }^{+}$endothelial tip cell is characterized by a TNT-like process (arrow), a number of shorter, exploring filopodia, and a cloud of tip cell-associated microvescicles, confront with a GBM mimicking vessel sprout (d, arrow) formed by CD31 ${ }^{+}$glioblastoma cell-derived ECs [90, 92], surrounded by a disassembled collagen IV basal lamina and numerous, scattered, CD31+ cells. This growing structure closely resembles glioblastoma cells described migration in vitro through a 3D matrix [91]. Scale bars a, b $20 \mu \mathrm{m} ; \mathbf{c}$, d $10 \mu \mathrm{m}$

Once intrinsic ENS NCCs reach the foregut, they are referred to as enteric neural crest-derived cells (ENCCs). The classical theory is that ENCCs undergo unimodal rostral-to-caudal migration within the gut mesenchyme to colonize the entire length of the gut. This theory is now being challenged by alternative models envisaging a trans-mesenteric migration of NCCs. Using timelapse imaging analyses of mouse ENCCs, Nishiyama et al. [306] captured an ENCC population that crosses from the midgut to the hindgut via the mesentery during a developmental time period in which these gut regions are transiently juxtaposed. They proposed that such 'transmesenteric' ENCCs constitute a large part of the hindgut ENS. It is conceivable that during their migration, ENCCs contribute to mesentery vascularization, living behind 'angiogenic' PCs that, together with ECs of the common splanchnopleuric mesoderm, form composite vessels with a dual origin.

Interestingly, more than half of all the GBM microvessel PCs have a host origin from endogenous brain PCs, 
rather than from tumor stem cells and/or bone marrow progenitors. Recent findings obtained in a GL261 mouse glioma model, orthotopically implanted in mice, demonstrate that much of the tumor pericyte population is contributed by PDGFR- $\beta^{+} / \mathrm{NG}^{+}$re-activated PCs of the host cerebral cortex overlying the tumor [93]. Host brain-derived PCs have been identified as type-2, a pericyte subset that participates in normal angiogenesis and, when activated by the tumor, develops a strong tumor tropism. These PCs are integrated within the tumor vessels, and show specific angiogenic competence, being capable of inducing new vessel formation [102]. Overall, these data support the idea that NCC-derived forebrain $\mathrm{PCs}$ and their intrinsic angiogenic activity, displayed during human neocortex development, may spark neo-angiogenesis in both tumors and neurological diseases [103] (Table 1).

Finally, during chick NCC migration in living embryos, the presence of dynamic TNTs, involved in inter-NCC communication and cytoplasmic exchange, has been revealed [307], further supporting these cell structures as the common trait between forebrain, retinal, mesenteric and glioma PCs and their embryonic ancestors. Like in NCCs, PC-derived TNTs/MTs described in human cerebral cortex and in GBM may convey pro-angiogenic molecules, thus restricting the range of dispersion of spatial information and/or amplifying local signals in physiological and pathological vessel growth and collateralization [87].

\section{NG2 proteoglycan: a switch-on-off molecule involved in pericytes-driven angiogenesis}

PCs are adept at receiving external signaling, migrating and rapidly adapting to achieve functional tasks, that include duplication and differentiation, in virtue of their extraordinary pluripotentiality [38-42, $68,246,265,308]$. This important capacity is determined by the expression of molecules able to sense and capture signaling molecules released from the surrounding environment. One of these molecules is proteoglycan NG2, a single-pass, type I transmembrane proteoglycan [274, 275]. The NG2 protein core is composed of a large extracellular domain $(290 \mathrm{kD})$, carrying two to three glycosaminoglycan chains and a number of potential $N$-glycosylation sites, a single transmembrane tract, and a short cytoplasmic tail (8.5 kD) [309]. Nonetheless, NG2 can be expressed without chondroitin sulphate glycosaminoglycan chains, placing NG2 in the category of so-called parttime proteoglycans, specifically committed to bind, through the central domain of the core protein, basal lamina molecules [310-312] and a number of growth factors [274, 275, 311]. The involvement of NG2 in NVU/BBB organization has been demonstrated in vitro, where NG2 knockdown in PCs co-cultured with ECs reduces the endothelial barrier function [118] and in vivo in NG2-knock out mice, that show a modified arrangement of endothelial tight junction strands in cerebral cortex microvessels [10]. Even though NG2 displays little capacity for independent signal transduction, it is actually a regulator of cell surface domains and growth factor activities [275, 313]. In addition, working as a type I membrane protein, NG2 is subject to intramembrane proteolysis (RIP) regulated by $\alpha$ - and $\gamma$-secretases. The product of endogenous $\alpha$-secretase action is the release of the NG2 ectodomain into the extracellular matrix. This process is termed shedding of soluble NG2 (sNG2) fragments [314-320]; four NG2 fragments have been associated with different biological functions in the CNS [321, 322]. The remaining C-terminal fragment undergoes a subsequent cleavage by $\gamma$-secretase, with the formation of an intracellular functional peptide, termed the released intracellular domain. The variety of NG2 and sNG2 biological roles has been investigated in $\mathrm{NG}_{2}^{+}$OPCs, where NG2 is maintained in mitotic active cells [323, 324] and is gradually downregulated until it disappears at the end of cell differentiation [325]. NG2 regulates cell motility via Rho/ GTPase and polarity complex proteins [326] and has neuroprotective effects [327]. NG2 shedding from the OPC surface modulates the neuronal network and, in NG2 knock out mice, those neurons surrounding OPCs exhibit diminished AMPA ( $\alpha$-amino3-hydroxy-5-methyl-4-isoxazolepropionic acid) and NMDA (N-methyl-D-aspartate) receptor-dependent current amplitudes [316, 322]. Interestingly, in the adult brain, $\mathrm{NG}^{+}$OPCs (also referred to as NG2glia) contact neurons at axonal nodes of Ranvier and, in close proximity to synapses at neuronal cell bodies, express ion channels [328-331]. They increase NG2 RIP after neuronal activity, producing a functional switch toward the cell cycle $\mathrm{S}$ phase, and also increasing protein mRNA translation into proteins by modulating mTOR signaling components [332]. These observations may be pertinent to other NG2 expressing cells, especially immature/activated PCs. In fact, shed NG2 has been demonstrated to promote angiogenesis and migration of ECs via binding of sNG2 to galectin- 3 and $\alpha 3 \beta 1$ integrin on the ECs, demonstrating that pericyte-derived NG2 is an important factor in promoting EC migration and morphogenesis during the early stages of neovascularization [295]. These include the formation of pericyte TNTs/MTs or 
effective pericyte conduits during both normal brain vascularization and tumoral neo-vessel formation [87, 88] (Figs. 7, 8, and Additional file 1: Figure S1). Accordingly, a decreased level of NG2 has been measured in cerebrospinal fluids derived from patients affected by Alzheimer's disease [333] and Lewy bodies dementia [113], where pericyte-altered clearance of amyloid impedes vascular integrity and endothelial regeneration [317, 334-336]. Endothelial regeneration is also tightly regulated by endothelial/pericyte contacts through the activation of Notch1 RIP in a bone morphogenetic protein receptor 2-dependent pathway [337], although the effect of pericytes NG2 RIP has not yet been reported.

\section{The CXCL12/CXCR4 axis is involved in NCSC-derived pericytes signaling}

The expression of CXCR4 (chemokine C-X-C motif receptor 4) by forebrain PCs during vessel sprout formation is coincident with the demonstrated role of chemokine signaling in NCC migration. Chemokine CXCL12 (C-X-C motif chemokine ligand 12 or stromal cell-derived factor 1, SDF-1) and its cognate receptors CXCR4 and CXCR7 (chemokine C-X-C motif receptor 7) have been implicated in the regulation of cell migration in a variety of tissues and conditions, also during human brain neurogenesis and vascularization [181]. CXCR4 is required for the migration of many stem cell and progenitor cell populations from their respective niches to the differentiating tissues and organs, and it has been identified as a key component for NCC migration [338]. In addition, specific CXCR4 antagonists (AMD3100 and TN14003) disrupt the migration of mesencephalic NCCs, suggesting a role for CXCL12/ CXCR4 signaling in the directed migration of mesencephalic NCCs in the early embryonic stages [339, 340]. The first, penetrating microvessels are followed by further waves of radial vessels that also elongate to parallel the progressively increasing width of the neural wall. At this time, typical endothelial sprouts coexist with a variety of forebrain PC-driven angiogenesis-associated structures [84] and, together with the classical signaling systems [127], alternative pathways, such as the CXCL12/CXCR4/CXCR7 ligand receptors systems, are involved in radial glia-like stem cells-microvessel and endothelial-pericyte interactions that are also seen to include pericyte TNT/MT structures (Fig. 9). In particular, in the developing cerebral cortex, chemokine CXCL12 is highly expressed by radial glia-like stem cells, immature radial astrocytes, perivascular astrocyte endfeet, and activated, $\mathrm{CD} 105^{+}$endothelial tip cells, while CXCR4 appears to be specifically expressed by sprout-associated PCs and migrating neuroblasts [180, 181] (Figs. 9, 10).

\section{Conclusions}

An ample heterogeneity has been reported in PCs even in the same organs [71]; for example, brain PCs have distinct morphologies, markers, and functions along the arteriole-capillary-venule vascular bed [70]. In addition, PCs can have a heterogeneous origin, even within the same tissue. In the embryo, the forebrain (telencephalon and diencephalon) is the only part of the developing CNS into which mesencephalic NCCs penetrate, giving origin to a subpopulation of forebrain PCs. During human neocortex development and vascularization, NCC-derived, activated forebrain PCs are present as early as mitotic ECs, and almost completely ensheath the endothelial lining, forming de facto a tube-within-a-tube bi-layered vessel wall and participating in the very early steps of cortex angiogenesis. In the cortex, forebrain PCs give origin to TNTs, MTs, and autonomous conduits and leading sprouts, their state of angiogenic activation being always marked by the expression of proteoglycan NG2, adhesion molecule CD146, and chemokine receptor CXCR4. Proteoglycan NG2, also known as 'high molecular weight melanoma-associated antigen' (HMW-MAA), is also expressed by NCC-derived melanocytes, while the other two molecules are expressed by migrating NCCs and, according to our results, are still expressed by forebrain PCs (Figs. 5, 10).

Forebrain PCs may perform better than other CNS PCs in maintaining the BBB endothelial phenotype, stabilizing EC cord formation 'in vitro' $[266,341]$ and inducing barrier properties in primary and hematopoietic stem cell-derived ECs [259, 342, 343]. PCs denoted as 'forebrain PCs' are critical regulators of EC functions, including cerebral blood-flow and BBB regulation, as well as tube-formation. Models that recapitulate forebrain PCs in vivo ontogeny, by deriving them from hiPSCs in vitro via a neural crest intermediate, showed a cellular, behavioral and functional equivalence to in vitroderived and in vivo-isolated normal, human forebrain PCs. This equivalence was demonstrated by cell migration and contractility assays and by the expression of genes associated with PC-specific biological processes, such as vesicular transport, formation, organization, and interaction of extracellular matrix, cell migration, contractility and angiogenesis [344]. hiPSCs can generate mesodermal cells and NCCs that can be induced to form mesoderm- and NCC-derived subpopulations 

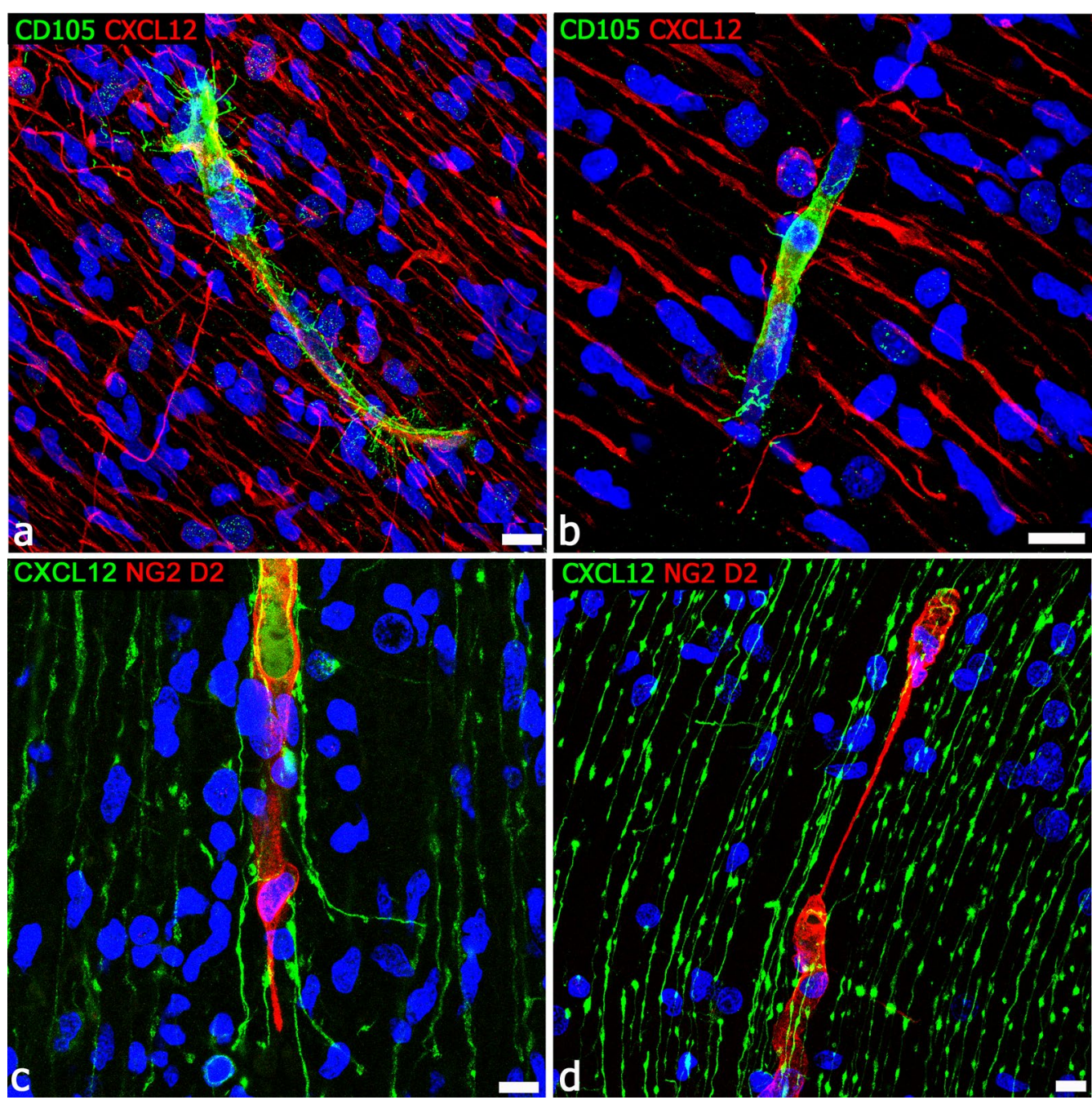

Fig. 9 Interaction of chemokine CXCL12 ${ }^{+}$radial glia with endothelial sprouts and pericyte TNTs. a, b Typical CD105 ${ }^{+}$growing vessels, characterized by tip cells and filopodial processes, appear in extensive contact with $\mathrm{CXCL} 12^{+}$radial glia fibers. $\mathbf{c}, \mathbf{d ~ N G} 2^{+}$forebrain pericyte TNTs are contacted by CXCL12 $2^{+}$radial glia fibers. Human telencephalon 22 weeks of gestation. Scale bars a $25 \mu \mathrm{m} ; \mathbf{b} 10 \mu \mathrm{m}$

of PCs, that specifically express the mesodermal genes, MIXL1 and TBXT, and NCCs genes, PAX3, PAX7 and TFAP2A [82, 345]. These findings promise to propel further investigation of specific roles of forebrain PCs, especially angiogenic properties, which are not yet fully understood. Accordingly, it will be crucial to explore transcriptional or epigenetic landscapes of forebrain PCs during angiogenesis, and neurovascular barrier properties in vivo, in vitro, and in different CNS diseases. The availability of single-cell RNA sequencing approaches, coupled with both genetic and pharmacological perturbations of forebrain PCs, makes it possible to identify signaling pathways that are triggered in the endothelialforebrain PCs crosstalk to modulate angiogenesis and barriergenesis under such different conditions. A better knowledge of the ontogenetic PCs subpopulations may help to understand specific interactions and mechanisms involved in pericyte function/dysfunction, including normal and pathological angiogenesis, thereby offering an alternative perspective on cell subtype-specific therapeutic approaches. These studies could not only strengthen our understanding of the complex mechanisms involved in aberrant/tumoral vessel growth, but also provide us with new avenues for managing neurological diseases that could recognize angiogenic PCs as concurrent effectors in NVU 'microvasculopathy', suggesting therapeutic approaches that target both 

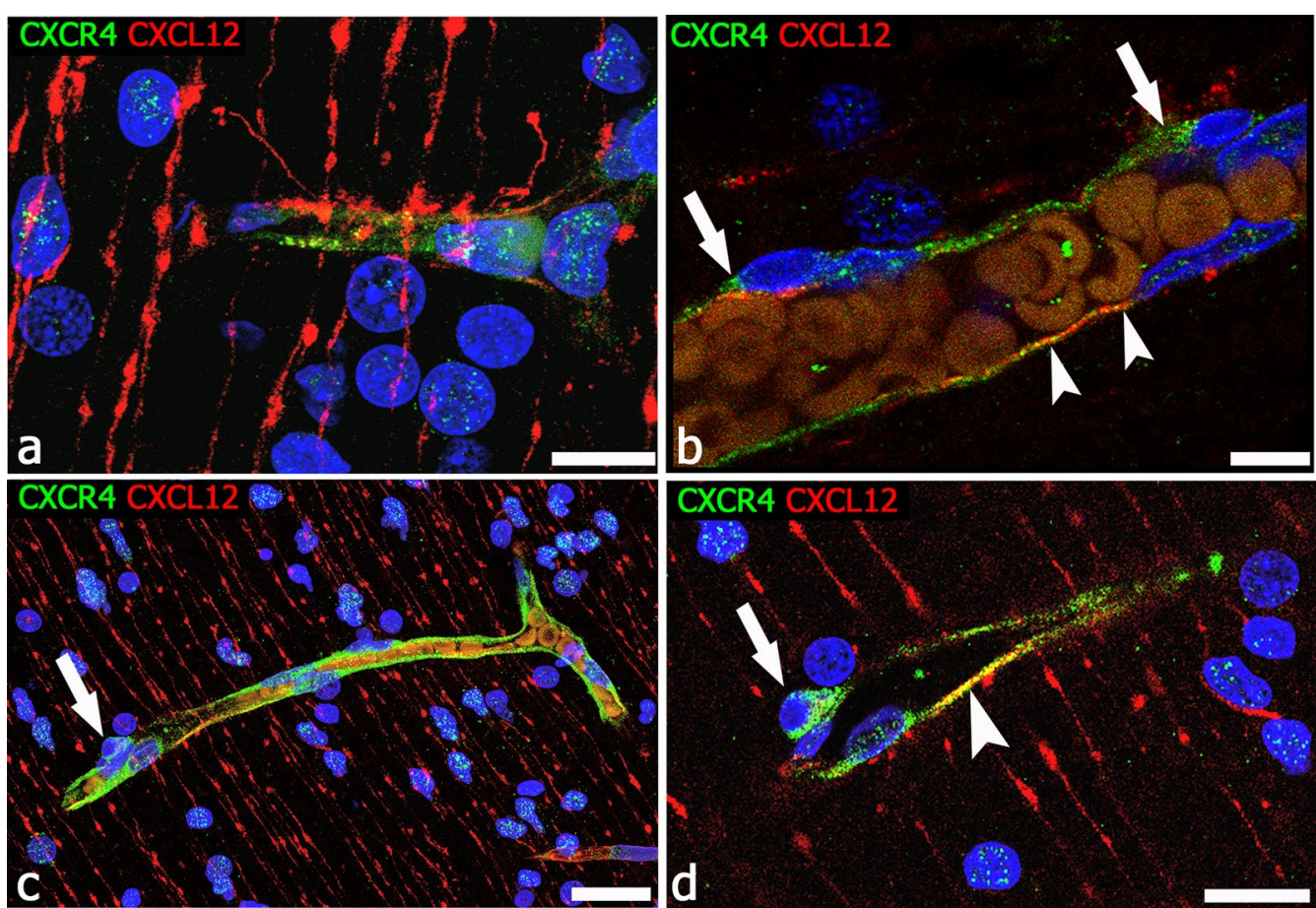

Fig. 10 CXCL12/CXCR4 ligand receptor system interaction on ECs and PCs. a Radial glia stains for CXCL12 and forms extensive contacts with the CXCR4 ${ }^{+}$vessel wall; CXCR4 also marks neuroblasts nuclei. b CXCR4 reveals forebrain PCs (arrows), while CXCL12 is prevalent on ECs (arrowheads). c CXCR4 stains the wall of a vessel collateral and its PCs (arrow). $\mathbf{d}$ Enlargement of the pericyte shown in c (arrow) and a tract of CXCL12/CXCR4 colocalization on the vessel wall (arrowhead). CXCR4 nuclear expression in neuroblasts is the hallmark of their activated phenotype [346, 347]. Human telencephalon 22 weeks of gestation. Scale bars $\mathbf{a}, \mathbf{b} 10 \mu \mathrm{m} ; \mathbf{c}, \mathbf{d} 25 \mu \mathrm{m}$

endothelial and the NCC/forebrain PC-specific angiogenic phenotypes and genotypes.

\section{Abbreviations \\ AMPA: a-Amino-3-hydroxy-5-methyl-4-isoxazolepropionic acid; BBB: Blood- brain barrier; CNS: Central nervous system; EC: Endothelial cell; ENCCs: Enteric neural crest-derived Cells; ENS: Enteric nervous system; GBM: Glioblastoma multiforme; Glut 1: Glucose transporter isoform 1; hiPSC: Human induced pluripotent stem cell; MMP: Matrix metalloproteinase; MT: Microtube; mTOR: Mammalian target of rapamycin; NCC: Neural-crest cells; NCSC: Neural-crest stem cell; NG2: Neuron-glial antigen 2; NMDA: $N$-methyl-D-aspartate; NVU: Neuro-vascular unit; OPC: Oligodendrocyte precursors cell; PDGF-B: Platelet- derived growth factor-B; PDGFR- $\beta$ : Platelet-derived growth factor receptor- $\beta$; PC: Pericyte; RIP: Regulated intramembrane proteolysis; sNG2: Soluble NG2; TGF- $\beta$ : Transforming growth factor- $\beta$; TM: Tumor microtube; TNF-a: Tumor necrosis factor-a; TNTs: Tunneling nanotubes; VEGF: Vascular endothelial growth factor; VEGFR 2: Vascular endothelial growth factor receptor 2.Sup- plementary information \\ The online version contains supplementary material available at https://doi. org/10.1186/s12987-021-00242-7.}

Additional file 1: Figure S1. The sequence of 34 single optical planes, from a z-stack image double stained with the endothelial marker CD31 (green) and the pericyte marker NG2 (red), shows a growing microvessel formed by a leading pericyte-derived endothelialized conduit. Human telencephalon 22 weeks of gestation. Original magnification $60 x$.
Additional file 2: Figure S2. Transmission electron microscopy images of newly-formed vessels in developing chick embryo brain. a A non-lumenalized microvessel with a continuous pericyte coverage (arrowheads), with few short projections toward the neuropil (arrows). b, c Small, lumenalized microvessels ensheathed by PCs (arrowheads). (from [5] with permission). Scale bars $\mathbf{a}, \mathbf{b}, \mathbf{c} 3 \mu \mathrm{m}$.

\section{Acknowledgements}

The authors gratefully acknowledge Prof. Bill Stallcup for the generous NG2D2 polyclonal antibody gift and Prof. Roberto Perris for the longstanding collaboration on monoclonal NG2 antibodies. They would like to thank M.V.C. Pragnell, BA, for language help, Francesco Fumai and Michelina de Giorgis for technical assistance.

Dedicated to Julia B. Platt (1857-1935): pioneer embryologist, neuroscientist, and civic leader. Despite her excellent scientific activity, Dr. Platt could not find a suitable academic position and in 1899 wrote, "Without work, life is not worth living. If I cannot obtain the work I wish, then I must take up with the next best... . . Dr. Platt became Pacific Grove's first female mayor in 1932.

\section{Authors' contributions}

FG, IT and DV designed the overall structure of this review and IT, ME provided detailed input to specific sections. FG and DV wrote the manuscript. Figures were designed by ME, DV, and illustrated by GL, Ad'A. FG edited the manuscript. All authors read and approved the final manuscript.

\section{Funding}

This study was not funded. 


\section{Availability of data and materials}

Not applicable.

\section{Ethics approval and consent to participate}

Samples of fetal brain were obtained from post-mortem fetuses derived from spontaneous abortions and received by the Department of Emergency and Organ Transplantation, Division of Anatomical Pathology, University of Bari School of Medicine. The study was reviewed and approved from the Medical Ethics Committee of University Hospital of Bari, in compliance with the principles stated in the Declaration of Helsinki. Samples from glioblastoma were obtained during surgery at the Department of Neurosurgery, University Hospital Zurich. Written informed consent was obtained from patients before study entry. All procedures were conducted in accordance with the principles stated in the Declaration of Helsinki and the study was approved by the Ethics Committee of the Canton Zurich.

\section{Consent for publication}

All Authors of the manuscript have read and agreed to its content and are accountable for all aspects of the accuracy and integrity of the manuscript in accordance with ICMJE criteria.

\section{Competing interests}

All the authors declare that they have no competing interests.

\section{Author details}

${ }^{1}$ Department of Basic Medical Sciences, Neuroscience and Sensory Organs, Human Anatomy and Histology Unit, University of Bari School of Medicine, Bari, Italy. ${ }^{2}$ Intensive Care Unit, Department of Intensive Care, Regional Hospital of Lugano, Ente Ospedaliero Cantonale, Lugano, Switzerland. ${ }^{3}$ Department of Basic Medical Sciences, Neuroscience and Sensory Organs, Molecular Biology Unit, University of Bari School of Medicine, Bari, Italy. ${ }^{4}$ Department of Emergency and Organ Transplantation, Pathology Section, University of Bari School of Medicine, Bari, Italy.

Received: 28 September 2020 Accepted: 13 February 2021

\section{Published online: 20 March 2021}

\section{References}

1. Rouget $C$. Note sur le developpement de la tunique contractile des vaisseaux. Compt Rend Acad Sci. 1874;59:559-62.

2. Zimmermann KW. Der feinere Bau der Blutcapillaren. Ztschr Anat u Entw Geschicht. 1923;68:29-109.

3. Allsopp G, Gamble HJ. An electron microscopic study of the pericytes of the developing capillaries in human fetal brain and muscle. J Anat. 1979;128(Pt 1):155-68.

4. King JS, Schwyn RC. The fine structure of neuroglial cells and pericytes in the primate red nucleus and substantia nigra. Z Zellforsch Mikrosk Anat. 1970;106(3):309-21.

5. Bertossi M, Riva A, Congiu T, Virgintino D, Nico B, Roncali L. A compared TEM/SEM investigation on the pericytic investment in developing microvasculature of the chick optic tectum. J Submicrosc Cytol Pathol. 1995;27(3):349-58.

6. Mathiisen TM, Lehre KP, Danbolt NC, Ottersen OP. The perivascular astroglial sheath provides a complete covering of the brain microvessels: an electron microscopic 3D reconstruction. Glia. 2010;58(9):1094-103.

7. Rucker HK, Wynder HJ, Thomas WE. Cellular mechanisms of CNS pericytes. Brain Res Bull. 2000;51(5):363-9.

8. Bonkowski D, Katyshev V, Balabanov RD, Borisov A, Dore-Duffy P. The CNS microvascular pericyte: pericyte-astrocyte crosstalk in the regulation of tissue survival. Fluids Barriers CNS. 2011;8(1):8

9. Hawkins BT, Davis TP. The blood-brain barrier/neurovascular unit in health and disease. Pharmacol Rev. 2005;57(2):173-85.

10. Girolamo F, Errede M, Longo G, Annese T, Alias C, Ferrara G, et al. Defining the role of NG2-expressing cells in experimental models of multiple sclerosis A biofunctional analysis of the neurovascular unit in wild type and NG2 null mice. PLOS ONE. 2019;14(3):e0213508.

11. Villabona-Rueda A, Erice C, Pardo CA, Stins MF. The evolving concept of the blood brain barrier (BBB): from a single static barrier to a heterogeneous and dynamic Relay Center. Front Cell Neurosci. 2019;13:405.
12. De Luca C, Colangelo AM, Virtuoso A, Alberghina L, Papa M. Neurons, glia, extracellular matrix and neurovascular unit: a systems biology approach to the complexity of synaptic plasticity in health and disease. Int J Mol Sci. 2020;21(4):1539.

13. Uemura MT, Maki T, Ihara M, Lee VMY, Trojanowski JQ. Brain microvascular pericytes in vascular cognitive impairment and dementia. Front Aging Neurosci. 2020;12:80.

14. ladecola $C$. The neurovascular unit coming of age: a journey through neurovascular coupling in health and disease. Neuron. 2017:96(1):17-42.

15. Liebner S, Dijkhuizen RM, Reiss Y, Plate KH, Agalliu D, Constantin G. Functional morphology of the blood-brain barrier in health and disease. Acta Neuropathol. 2018;135(3):311-36.

16. Leveen P, Pekny M, Gebre-Medhin S, Swolin B, Larsson E, Betsholtz C. Mice deficient for PDGF B show renal, cardiovascular, and hematological abnormalities. Genes Dev. 1994:8(16):1875-87.

17. Soriano P. Abnormal kidney development and hematological disorders in PDGF beta-receptor mutant mice. Genes Dev. 1994;8(16):1888-96.

18. Lindahl $P$, Johansson BR, Leveen $P$, Betsholtz C. Pericyte loss and microaneurysm formation in PDGF-B-deficient mice. Science. 1997;277(5323):242-5

19. Hellstrom M, Gerhardt H, Kalen M, Li X, Eriksson U, Wolburg H, et al. Lack of pericytes leads to endothelial hyperplasia and abnormal vascular morphogenesis. J Cell Biol. 2001;153(3):543-53.

20. Enge M, Bjarnegard M, Gerhardt H, Gustafsson E, Kalen M, Asker N, et al. Endothelium-specific platelet-derived growth factor-B ablation mimics diabetic retinopathy. EMBO J. 2002:21(16):4307-16.

21. Bischoff FC, Werner A, John D, Boeckel JN, Melissari MT, Grote P, et al. Identification and functional characterization of hypoxia-induced endoplasmic reticulum stress regulating IncRNA (HypERInc) in pericytes. Circ Res. 2017;121(4):368-75.

22. Li Q, Liu X, Ruan H, Chen Y, Feng H. Pericyte: potential target for hemorrhagic stroke prevention and treatment. Curr Drug Deliv. 2017;14(6):773-84

23. Heymans M, Figueiredo R, Dehouck L, Francisco D, Sano Y, Shimizu $F$, et al. Contribution of brain pericytes in blood-brain barrier formation and maintenance: a transcriptomic study of cocultured human endothelial cells derived from hematopoietic stem cells. Fluids Barriers CNS. 2020;17(1):48.

24. Rom S, Gajghate S, Winfield M, Reichenbach NL, Persidsky Y Combination of HIV-1 and diabetes enhances blood brain barrier injury via effects on brain endothelium and pericytes. Int J Mol Sci. 2020;21(13):4663.

25. Stark K, Eckart A, Haidari S, Tirniceriu A, Lorenz M, von Bruhl ML, et al. Capillary and arteriolar pericytes attract innate leukocytes exiting through venules and 'instruct' them with pattern-recognition and motility programs. Nat Immunol. 2013;14(1):41-51.

26. Rudziak P, Ellis CG, Kowalewska PM. Role and molecular mechanisms of pericytes in regulation of leukocyte diapedesis in inflamed tissues. Mediators Inflamm. 2019;2019:4123605.

27. Zhang Y, Barres BA. Astrocyte heterogeneity: an underappreciated topic in neurobiology. Curr Opin Neurobiol. 2010;20(5):588-94.

28. Zhang Y, Chen K, Sloan SA, Bennett ML, Scholze AR, O'Keeffe S, et al. An RNA-sequencing transcriptome and splicing database of glia, neurons, and vascular cells of the cerebral cortex. J Neurosci. 2014:34(36):11929-47.

29. Li Q, Cheng Z, Zhou L, Darmanis S, Neff NF, Okamoto J, et al. Developmental heterogeneity of microglia and brain myeloid cells revealed by deep single-cell RNA sequencing. Neuron. 2019;101(2):207-23.

30. Batiuk MY, Martirosyan A, Wahis J, de Vin F, Marneffe C, Kusserow C, et al. Identification of region-specific astrocyte subtypes at single cell resolution. Nat Commun. 2020;11(1):1220.

31. van der Poel M, Ulas T, Mizee MR, Hsiao CC, Miedema SSM, Adelia, et al. Transcriptional profiling of human microglia reveals grey-white matter heterogeneity and multiple sclerosis-associated changes. Nat Commun. 2019:10(1):1139.

32. Masuda T, Sankowski R, Staszewski O, Bottcher C, Amann L, Sagar, et al. Spatial and temporal heterogeneity of mouse and human microglia at single-cell resolution. Nature. 2019;566(7744):388-92. 
33. Liddelow SA, Guttenplan KA, Clarke LE, Bennett FC, Bohlen CJ, Schirmer $L$, et al. Neurotoxic reactive astrocytes are induced by activated microglia. Nature. 2017;541(7638):481-7.

34. Masuda T, Sankowski R, Staszewski O, Prinz M. Microglia heterogeneity in the single-cell era. Cell Rep. 2020;30(5):1271-81.

35. Crouch EE, Doetsch F. FACS isolation of endothelial cells and pericytes from mouse brain microregions. Nat Protoc. 2018;13(4):738-51.

36. Dore-Duffy P, Esen N. The microvascular pericyte: approaches to isolation, characterization, and cultivation. Adv Exp Med Biol. 2018;1109:53-65

37. Sims D, Horne MM, Creighan M, Donald A. Heterogeneity of pericyte populations in equine skeletal muscle and dermal microvessels: a quantitative study. Anat Histol Embryol. 1994;23(3):232-8.

38. Tilton RG. Capillary pericytes: perspectives and future trends. J Electron Microsc Tech. 1991;19(3):327-44

39. Shepro D, Morel NM. Pericyte physiology. FASEB J. 1993;7(11):1031-8.

40. Balabanov R, Dore-Duffy P. Role of the CNS microvascular pericyte in the blood-brain barrier. J Neurosci Res. 1998;53(6):637-44.

41. Ding R, Darland DC, Parmacek MS, D'Amore PA. Endothelial-mesenchymal interactions in vitro reveal molecular mechanisms of smooth muscle/pericyte differentiation. Stem Cells Dev. 2004;13(5):509-20.

42. Dore-Duffy P, Katychev A, Wang X, Van Buren E. CNS microvascular pericytes exhibit multipotential stem cell activity. J Cereb Blood Flow Metab. 2006;26(5):613-24.

43. Davidoff MS. The pluripotent microvascular pericytes are the adult stem cells even in the testis. Adv Exp Med Biol. 2019;1122:235-67.

44. Zhang ZS, Zhou HN, He SS, Xue MY, Li T, Liu LM. Research advances in pericyte function and their roles in diseases. Chin J Traumatol. 2020;23(2):89-95.

45. Attwell D, Mishra A, Hall CN, O'Farrell FM, Dalkara T. What is a pericyte? J Cereb Blood Flow Metab. 2016;36(2):451-5.

46. Valero MC, Huntsman HD, Liu J, Zou K, Boppart MD. Eccentric exercise facilitates mesenchymal stem cell appearance in skeletal muscle. PLOS ONE. 2012;7(1):e29760.

47. Fabry Z, Fitzsimmons KM, Herlein JA, Moninger TO, Dobbs MB, Hart $M N$. Production of the cytokines interleukin 1 and 6 by murine brain microvessel endothelium and smooth muscle pericytes. J Neuroimmunol. 1993;47(1):23-34.

48. Girolamo F, Virgintino D, Errede M, Capobianco C, Bernardini $\mathrm{N}$, Bertossi $\mathrm{M}$, et al. Involvement of metalloprotease-2 in the development of human brain microvessels. Histochem Cell Biol. 2004;122(3):261-70.

49. Mendes-Jorge L, Llombart C, Ramos D, Lopez-Luppo M, Valenca A, Nacher $V$, et al. Intercapillary bridging cells: immunocytochemical characteristics of cells that connect blood vessels in the retina. Exp Eye Res. 2012;98:79-87.

50. Chaudhry AP, Montes M, Cohn GA. Ultrastructure of cerebellar hemangioblastoma. Cancer. 1978;42(4):1834-50.

51. Doherty MJ, Canfield AE. Gene expression during vascular pericyte differentiation. Crit Rev Eukaryot Gene Expr. 1999;9(1):1-17.

52. Gerhardt $\mathrm{H}$, Betsholtz C. Endothelial-pericyte interactions in angiogenesis. Cell Tissue Res. 2003;314(1):15-23.

53. Yamashita J, Itoh H, Hirashima M, Ogawa M, Nishikawa S, Yurugi T, et al. Flk1-positive cells derived from embryonic stem cells serve as vascular progenitors. Nature. 2000;408(6808):92-6.

54. Carmeliet P. Manipulating angiogenesis in medicine. J Intern Med. 2004;255(5):538-61.

55. Balabanov R, Washington R, Wagnerova J, Dore-Duffy P. CNS microvascular pericytes express macrophage-like function, cell surface integrin alpha $\mathrm{M}$, and macrophage marker ED-2. Microvasc Res. 1996;52(2):127-42.

56. Balabanov R, Beaumont T, Dore-Duffy P. Role of central nervous system microvascular pericytes in activation of antigen-primed splenic T-lymphocytes. J Neurosci Res. 1999;55(5):578-87.

57. Khan JA, Mendelson A, Kunisaki Y, Birbrair A, Kou Y, Arnal-Estape A, et al. Fetal liver hematopoietic stem cell niches associate with portal vessels. Science. 2016;351(6269):176-80.

58. Birbrair A, Zhang T, Wang ZM, Messi ML, Mintz A, Delbono O. Type-1 pericytes participate in fibrous tissue deposition in aged skeletal muscle. Am J Physiol Cell Physiol. 2013;305(11):C1098-113.
59. Birbrair A, Zhang T, Wang ZM, Messi ML, Enikolopov GN, Mintz A, et al. Role of pericytes in skeletal muscle regeneration and fat accumulation. Stem Cells Dev. 2013;22(16):2298-314.

60. Asada N, Kunisaki Y, Pierce H, Wang Z, Fernandez NF, Birbrair A, et al. Differential cytokine contributions of perivascular haematopoietic stem cell niches. Nat Cell Biol. 2017;19(3):214-23.

61. Karow M, Sanchez R, Schichor C, Masserdotti G, Ortega F, Heinrich C, et al. Reprogramming of pericyte-derived cells of the adult human brain into induced neuronal cells. Cell Stem Cell. 2012;11(4):471-6.

62. Paul G, Ozen I, Christophersen NS, Reinbothe T, Bengzon J, Visse E, et al. The adult human brain harbors multipotent perivascular mesenchymal stem cells. PLoS ONE. 2012;7(4):e35577.

63. Birbrair A, Zhang T, Wang ZM, Messi ML, Enikolopov GN, Mintz A, et al. Skeletal muscle neural progenitor cells exhibit properties of NG2-glia. Exp Cell Res. 2013;319(1):45-63.

64. Nakagomi T, Kubo S, Nakano-Doi A, Sakuma R, Lu S, Narita A, et al. Brain vascular pericytes following ischemia have multipotential stem cell activity to differentiate into neural and vascular lineage cells. Stem Cells. 2015;33(6):1962-74.

65. Sakuma R, Kawahara M, Nakano-Doi A, Takahashi A, Tanaka Y, Narita A, et al. Brain pericytes serve as microglia-generating multipotent vascular stem cells following ischemic stroke. J Neuroinflammation. 2016;13(1):57.

66. Birbrair A, Borges IDT, Gilson Sena IF, Almeida GG, da Silva Meirelles L, Goncalves R, et al. How plastic are pericytes? Stem Cells Dev. 2017;26(14):1013-9.

67. Guimaraes-Camboa N, Cattaneo P, Sun Y, Moore-Morris T, Gu Y, Dalton ND, et al. Pericytes of multiple organs do not behave as mesenchymal stem cells in vivo. Cell Stem Cell. 2017;20(3):345-59.

68. Dore-Duffy P. Pericytes: pluripotent cells of the blood brain barrier. Curr Pharm Des. 2008;14(16):1581-93.

69. Armulik A, Genove G, Betsholtz C. Pericytes: developmental, physiological, and pathological perspectives, problems, and promises. Dev Cell. 2011;21(2):193-215.

70. Hartmann DA, Underly RG, Grant RI, Watson AN, Lindner V, Shih AY. Pericyte structure and distribution in the cerebral cortex revealed by high-resolution imaging of transgenic mice. Neurophotonics. 2015;2(4):041402.

71. Dias Moura Prazeres PH, Sena IFG, Borges IDT, de Azevedo PO, Andreotti JP, de Paiva AE, et al. Pericytes are heterogeneous in their origin within the same tissue. Dev Biol. 2017;427(1):6-11.

72. Morikawa S, Baluk P, Kaidoh T, Haskell A, Jain RK, McDonald DM. Abnormalities in pericytes on blood vessels and endothelial sprouts in tumors. Am J Pathol. 2002;160(3):985-1000.

73. Kunisaki Y, Bruns I, Scheiermann C, Ahmed J, Pinho S, Zhang D, et al. Arteriolar niches maintain haematopoietic stem cell quiescence. Nature. 2013;502(7473):637-43.

74. Smyth LCD, Rustenhoven J, Scotter EL, Schweder P, Faull RLM, ParkTIH, et al. Markers for human brain pericytes and smooth muscle cells. J Chem Neuroanat. 2018;92:48-60.

75. Bergwerff M, Verberne ME, DeRuiter MC, Poelmann RE, Gittenbergerde Groot AC. Neural crest cell contribution to the developing circulatory system: implications for vascular morphology? Circ Res. 1998;82(2):221-31.

76. Etchevers HC, Vincent C, Le Douarin NM, Couly GF. The cephalic neural crest provides pericytes and smooth muscle cells to all blood vessels of the face and forebrain. Development. 2001;128(7):1059-68.

77. Korn J, Christ B, Kurz H. Neuroectodermal origin of brain pericytes and vascular smooth muscle cells. J Comp Neurol. 2002;442(1):78-88.

78. Asahina K, Zhou B, Pu WT, Tsukamoto H. Septum transversum-derived mesothelium gives rise to hepatic stellate cells and perivascular mesenchymal cells in developing mouse liver. Hepatology. 2011;53(3):983-95.

79. Winkler EA, Bell RD, Zlokovic BV. Central nervous system pericytes in health and disease. Nat Neurosci. 2011;14(11):1398-405.

80. Yamanishi E, Takahashi M, Saga Y, Osumi N. Penetration and differentiation of cephalic neural crest-derived cells in the developing mouse telencephalon. Dev Growth Differ. 2012;54(9):785-800.

81. Birbrair A, Zhang T, Wang ZM, Messi ML, Mintz A, Delbono O. Pericytes at the intersection between tissue regeneration and pathology. Clin Sci. 2015;128(2):81-93. 
82. Faal T, Phan DTT, Davtyan H, Scarfone VM, Varady E, Blurton-Jones M, et al. Induction of mesoderm and neural crest-derived pericytes from human pluripotent stem cells to study blood-brain barrier interactions. Stem Cell Reports. 2019;12(3):451-60.

83. Siegenthaler JA, Choe Y, Patterson KP, Hsieh I, Li D, Jaminet SC, et al. Foxc1 is required by pericytes during fetal brain angiogenesis. Biol Open. 2013;2(7):647-59

84. Virgintino D, Girolamo F, Errede M, Capobianco C, Robertson D, Stallcup $W B$, et al. An intimate interplay between precocious, migrating pericytes and endothelial cells governs human fetal brain angiogenesis. Angiogenesis. 2007;10(1):35-45.

85. Virgintino D, Maiorano E, Errede M, Vimercati A, Greco P, Selvaggi L, et al. Astroglia-microvessel relationship in the developing human telencephalon. Int J Dev Biol. 1998:42(8):1165-8.

86. Ozerdem U, Stallcup WB. Pathological angiogenesis is reduced by targeting pericytes via the NG2 proteoglycan. Angiogenesis. 2004;7(3):269-76.

87. Errede M, Mangieri D, Longo G, Girolamo F, de Trizio I, Vimercati A, et al. Tunneling nanotubes evoke pericyte/endothelial communication during normal and tumoral angiogenesis. Fluids Barriers CNS. 2018;15(1):28

88. Girolamo F, Dallatomasina A, Rizzi M, Errede M, Walchli T, Mucignat MT, et al. Diversified expression of NG2/CSPG4 isoforms in glioblastoma and human foetal brain identifies pericyte subsets. PLOS ONE. 2013;8(12):e84883.

89. Ozerdem U, Stallcup WB. Early contribution of pericytes to angiogenic sprouting and tube formation. Angiogenesis. 2003;6(3):241-9.

90. El Hallani S, Boisselier B, Peglion F, Rousseau A, Colin C, Idbaih A, et al. A new alternative mechanism in glioblastoma vascularization: tubular vasculogenic mimicry. Brain. 2010;133(Pt 4):973-82.

91. Zhong J, Paul A, Kellie SJ, O'Neill GM. Mesenchymal migration as a therapeutic target in glioblastoma. J Oncol. 2010;2010:430142.

92. Mei X, Chen YS, Chen FR, Xi SY, Chen ZP. Glioblastoma stem cell differentiation into endothelial cells evidenced through live-cell imaging. Neuro Oncol. 2017;19(8):1109-18.

93. Svensson A, Ozen I, Genove G, Paul G, Bengzon J. Endogenous brain pericytes are widely activated and contribute to mouse glioma microvasculature. PLoS ONE. 2015;10(4):e0123553.

94. Guerra DAP, Paiva AE, Sena IFG, Azevedo PO, Silva WN, Mintz A, et al. Targeting glioblastoma-derived pericytes improves chemotherapeutic outcome. Angiogenesis. 2018;21(4):667-75.

95. Wilm B, Ipenberg A, Hastie ND, Burch JB, Bader DM. The serosal mesothelium is a major source of smooth muscle cells of the gut vasculature. Development. 2005;132(23):5317-28.

96. Mellgren AM, Smith CL, Olsen GS, Eskiocak B, Zhou B, Kazi MN, et al. Platelet-derived growth factor receptor beta signaling is required for efficient epicardial cell migration and development of two distinct coronary vascular smooth muscle cell populations. Circ Res. 2008;103(12):1393-401.

97. Que J, Wilm B, Hasegawa H, Wang F, Bader D, Hogan BL. Mesothelium contributes to vascular smooth muscle and mesenchyme during lung development. Proc Natl Acad Sci U S A. 2008;105(43):16626-30.

98. Cai X, Lin Y, Hauschka PV, Grottkau BE. Adipose stem cells originate from perivascular cells. Biol Cell. 2011;103(9):435-47.

99. Birbrair A, Zhang T, Files DC, Mannava S, Smith T, Wang ZM, et al. Type-1 pericytes accumulate after tissue injury and produce collagen in an organ-dependent manner. Stem Cell Res Ther. 2014;5(6):122.

100. Wiegreffe C, Christ B, Huang R, Scaal M. Remodeling of aortic smooth muscle during avian embryonic development. Dev Dyn. 2009;238(3):624-31

101. Pouget C, Pottin $K$, Jaffredo T. Sclerotomal origin of vascular smooth muscle cells and pericytes in the embryo. Dev Biol. 2008;315(2):437-47.

102. Birbrair A, Zhang T, Wang ZM, Messi ML, Olson JD, Mintz A, et al. Type-2 pericytes participate in normal and tumoral angiogenesis. Am J Physiol Cell Physiol. 2014;307(1):C25-38.

103. Jackson S, EIAli A, Virgintino D, Gilbert MR. Blood-brain barrier pericyte importance in malignant gliomas: what we can learn from stroke and Alzheimer's disease. Neuro Oncol. 2017;19(9):1173-82.

104. Yamamoto S, Muramatsu M, Azuma E, Ikutani M, Nagai Y, Sagara H, et al. A subset of cerebrovascular pericytes originates from mature macrophages in the very early phase of vascular development in CNS Sci Rep. 2017;7(1):3855.

105. Yamazaki T, Nalbandian A, Uchida Y, Li W, Arnold TD, Kubota Y, et al. Tissue myeloid progenitors differentiate into pericytes through TGF-beta signaling in developing skin vasculature. Cell Rep. 2017;18(12):2991-3004.

106. Fantin A, Vieira JM, Gestri G, Denti L, Schwarz Q, Prykhozhij S, et al. Tissue macrophages act as cellular chaperones for vascular anastomosis downstream of VEGF-mediated endothelial tip cell induction. Blood. 2010;116(5):829-40

107. Stefater JA 3rd, Lewkowich I, Rao S, Mariggi G, Carpenter AC, Burr AR, et al. Regulation of angiogenesis by a non-canonical Wnt-Flt1 pathway in myeloid cells. Nature. 2011:474(7352):511-5.

108. Bababeygy SR, Cheshier SH, Hou LC, Higgins DM, Weissman IL, Tse VC Hematopoietic stem cell-derived pericytic cells in brain tumor angioarchitecture. Stem Cells Dev. 2008;17(1):11-8.

109. Stallcup WB. The NG2 proteoglycan: past insights and future prospects. J Neurocytol. 2002;31 (6-7):423-35.

110. He L, Vanlandewijck M, Raschperger E, Andaloussi Mae M, Jung B, Lebouvier T, et al. Analysis of the brain mural cell transcriptome. Sci Rep. 2016;6:35108

111. Ozerdem U, Grako KA, Dahlin-Huppe K, Monosov E, Stallcup WB. NG2 proteoglycan is expressed exclusively by mural cells during vascular morphogenesis. Dev Dyn. 2001;222(2):218-27.

112. Ruiter DJ, Schlingemann RO, Westphal JR, Denijn M, Rietveld FJ, De Waal RM. Angiogenesis in wound healing and tumor metastasis. Behring Inst Mitt. 1993;92:258-72.

113. Nielsen HM, Hall S, Surova Y, Nagga K, Nilsson C, Londos E, et al. Low levels of soluble NG2 in cerebrospinal fluid from patients with dementia with Lewy bodies. J Alzheimers Dis. 2014;40(2):343-50.

114. Schlingemann RO, Rietveld FJ, de Waal RM, Ferrone S, Ruiter DJ. Expression of the high molecular weight melanoma-associated antigen by pericytes during angiogenesis in tumors and in healing wounds. Am J Pathol. 1990;136(6):1393-405

115. Ozerdem U. Targeting neovascular pericytes in neurofibromatosis type 1. Angiogenesis. 2004;7(4):307-11.

116. Ferrara G, Errede M, Girolamo F, Morando S, Ivaldi F, Panini N, et al. NG2, a common denominator for neuroinflammation, blood-brain barrier alteration, and oligodendrocyte precursor response in EAE, plays a role in dendritic cell activation. Acta Neuropathol. 2016;132(1):23-42.

117. Kucharova K, Chang Y, Boor A, Yong VW, Stallcup WB. Reduced inflammation accompanies diminished myelin damage and repair in the NG2 null mouse spinal cord. J Neuroinflammation. 2011;8:158.

118. You WK, Yotsumoto F, Sakimura K, Adams RH, Stallcup WB. NG2 proteoglycan promotes tumor vascularization via integrin-dependent effects on pericyte function. Angiogenesis. 2014;17(1):61-76.

119. Stallcup WB, You WK, Kucharova K, Cejudo-Martin P, Yotsumoto F. NG2 proteoglycan-dependent contributions of pericytes and macrophages to brain tumor vascularization and progression. Microcirculation. 2016;23(2):122-33.

120. Lama G, Mangiola A, Proietti G, Colabianchi A, D'Angelucci C, Dlessio $D A$, et al. Progenitor/stem cell markers in brain adjacent to glioblastoma: GD3 ganglioside and NG2 proteoglycan expression. J Neuropathol Exp Neurol. 2016;75(2):134-47.

121. Chekenya M, Enger PO, Thorsen F, Tysnes BB, Al-Sarraj S, Read TA, et al. The glial precursor proteoglycan, NG2, is expressed on tumour neovasculature by vascular pericytes in human malignant brain tumours. Neuropathol Appl Neurobiol. 2002;28(5):367-80.

122. Yotsumoto F, You WK, Cejudo-Martin P, Kucharova K, Sakimura K, Stallcup WB. NG2 proteoglycan-dependent recruitment of tumor macrophages promotes pericyte-endothelial cell interactions required for brain tumor vascularization. Oncoimmunology. 2015;4(4):e1001204.

123. Bhowmick S, D'Mello V, Caruso D, Wallerstein A, Abdul-Muneer PM. Impairment of pericyte-endothelium crosstalk leads to blood-brain barrier dysfunction following traumatic brain injury. Exp Neurol. 2019:317:260-70.

124. Hesp ZC, Yoseph RY, Suzuki R, Jukkola P, Wilson C, Nishiyama A, et al. Proliferating NG2-cell-dependent angiogenesis and scar formation alter axon growth and functional recovery after spinal cord injury in mice. J Neurosci. 2018;38(6):1366-82. 
125. Petrini S, Tessa A, Stallcup WB, Sabatelli P, Pescatori M, Giusti B, et al. Altered expression of the MCSP/NG2 chondroitin sulfate proteoglycan in collagen VI deficiency. Mol Cell Neurosci. 2005;30(3):408-17.

126. Kmiecik J, Gras Navarro A, Poli A, Planaguma JP, Zimmer J, Chekenya M. Combining NK cells and mAb9.2.27 to combat NG2-dependent and anti-inflammatory signals in glioblastoma. Oncoimmunology. 2014:3(1):e27185.

127. Hellstrom M, Kalen M, Lindahl P, Abramsson A, Betsholtz C. Role of PDGF-B and PDGFR-beta in recruitment of vascular smooth muscle cells and pericytes during embryonic blood vessel formation in the mouse. Development. 1999;126(14):3047-55.

128. Jung B, Arnold TD, Raschperger E, Gaengel K, Betsholtz C. Visualization of vascular mural cells in developing brain using genetically labeled transgenic reporter mice. J Cereb Blood Flow Metab. 2018;38(3):456-68.

129. Miners JS, Schulz I, Love S. Differing associations between Abeta accumulation, hypoperfusion, blood-brain barrier dysfunction and loss of PDGFRB pericyte marker in the precuneus and parietal white matter in Alzheimer's disease. J Cereb Blood Flow Metab. 2018:38(1):103-15.

130. Hutter-Schmid B, Humpel C. Platelet-derived growth factor receptorbeta is differentially regulated in primary mouse pericytes and brain slices. Curr Neurovasc Res. 2016;13(2):127-34.

131. Vanlandewijck M, He L, Mae MA, Andrae J, Ando K, Del Gaudio F, et al. A molecular atlas of cell types and zonation in the brain vasculature. Nature. 2018;554(7693):475-80.

132. Winkler EA, Bell RD, Zlokovic BV. Pericyte-specific expression of PDGF beta receptor in mouse models with normal and deficient PDGF beta receptor signaling. Mol Neurodegener. 2010;5:32.

133. Schultz N, Byman E, Fex M, Wennstrom M. Amylin alters human brain pericyte viability and NG2 expression. J Cereb Blood Flow Metab. 2017;37(4):1470-82.

134. Martinez-Valbuena I, Valenti-Azcarate R, Amat-Villegas I, Riverol M, Marcilla I, de Andrea CE, et al. Amylin as a potential link between type 2 diabetes and alzheimer disease. Ann Neurol. 2019;86(4):539-51.

135. Winkler EA, Sengillo JD, Sullivan JS, Henkel JS, Appel SH, Zlokovic BV. Blood-spinal cord barrier breakdown and pericyte reductions in amyotrophic lateral sclerosis. Acta Neuropathol. 2013;125(1):111-20.

136. Kisler K, Nelson AR, Rege SV, Ramanathan A, Wang Y, Ahuja A, et al. Pericyte degeneration leads to neurovascular uncoupling and limits oxygen supply to brain. Nat Neurosci. 2017;20(3):406-16.

137. Krupinski J, Issa R, Bujny T, Slevin M, Kumar P, Kumar S, et al. A putative role for platelet-derived growth factor in angiogenesis and neuroprotection after ischemic stroke in humans. Stroke. 1997;28(3):564-73.

138. Renner O, Tsimpas A, Kostin S, Valable S, Petit E, Schaper W, et al. Time- and cell type-specific induction of platelet-derived growth factor receptor-beta during cerebral ischemia. Brain Res Mol Brain Res. 2003:113(1-2):44-51.

139. Shen J, Xu G, Zhu R, Yuan J, Ishii Y, Hamashima T, et al. PDGFR-beta restores blood-brain barrier functions in a mouse model of focal cerebral ischemia. J Cereb Blood Flow Metab. 2019:39(8):1501-15.

140. Craggs $\sqcup$, Fenwick R, Oakley AE, Ihara M, Kalaria RN. Immunolocalization of platelet-derived growth factor receptor-beta (PDGFR-beta) and pericytes in cerebral autosomal dominant arteriopathy with subcortical infarcts and leukoencephalopathy (CADASIL). Neuropathol Appl Neurobiol. 2015;41(4):557-70.

141. Winkler EA, Birk H, Burkhardt JK, Chen X, Yue JK, Guo D, et al. Reductions in brain pericytes are associated with arteriovenous malformation vascular instability. J Neurosurg. 2018;129(6):1464-74.

142. Shibahara T, Ago T, Tachibana M, Nakamura K, Yamanaka K, Kuroda $J$, et al. Reciprocal interaction between pericytes and macrophage in poststroke tissue repair and functional recovery. Stroke. 2020;51(10):3095-106

143. Kyyriainen J, Ekolle Ndode-Ekane X, Pitkanen A. Dynamics of PDGFRbeta expression in different cell types after brain injury. Glia. 2017:65(2):322-41.

144. Goritz C, Dias DO, Tomilin N, Barbacid M, Shupliakov O, Frisen J. A pericyte origin of spinal cord scar tissue. Science. 2011;333(6039):238-42.

145. Jain RK, Booth MF. What brings pericytes to tumor vessels? J Clin Invest. 2003:112(8):1134-6

146. Kunz J, Krause D, Kremer M, Dermietzel R. The 140-kDa protein of blood-brain barrier-associated pericytes is identical to aminopeptidase N. J Neurochem. 1994:62(6):2375-86.
147. Alliot F, Rutin J, Leenen PJ, Pessac B. Pericytes and periendothelial cells of brain parenchyma vessels co-express aminopeptidase $\mathrm{N}$, aminopeptidase A, and nestin. J Neurosci Res. 1999:58(3):367-78.

148. Crouch EE, Liu C, Silva-Vargas V, Doetsch F. Regional and stage-specific effects of prospectively purified vascular cells on the adult V-SVZ neural stem cell lineage. J Neurosci. 2015;35(11):4528-39.

149. Dermietzel R, Krause D. Molecular anatomy of the blood-brain barrier as defined by immunocytochemistry. Int Rev Cytol. 1991;127:57-109.

150. Kunz J, Krause D, Gehrmann J, Dermietzel R. Changes in the expression pattern of blood-brain barrier-associated pericytic aminopeptidase $\mathrm{N}$ (PAP N) in the course of acute experimental autoimmune encephalomyelitis. J Neuroimmunol. 1995;59(1-2):41-55.

151. Gertz K, Kronenberg G, Uhlemann R, Prinz V, Marquina R, Corada M, et al. Partial loss of VE-cadherin improves long-term outcome and cerebral blood flow after transient brain ischemia in mice. BMC Neurol. 2016:16(1):144

152. Bandopadhyay R, Orte C, Lawrenson JG, Reid AR, De Silva S, Allt G. Contractile proteins in pericytes at the blood-brain and blood-retinal barriers. J Neurocytol. 2001;30(1):35-44.

153. Fujimoto T, Singer SJ. Immunocytochemical studies of desmin and vimentin in pericapillary cells of chicken. J Histochem Cytochem. 1987;35(10):1105-15

154. Kokovay E, Li L, Cunningham LA. Angiogenic recruitment of pericytes from bone marrow after stroke. J Cereb Blood Flow Metab. 2006;26(4):545-55.

155. Ding $X H$, Zhou LF, Tan YZ, Zhao Y, Zhu JJ. Histologic and histogenetic investigations of intracranial hemangioblastomas. Surg Neurol. 2007;67(3):239-45 discussion 45

156. Dardick I, Hammar SP, Scheithauer BW. Ultrastructural spectrum of hemangiopericytoma: a comparative study of fetal, adult, and neoplastic pericytes. Ultrastruct Pathol. 1989:13(2-3):111-54

157. Bondjers C, Kalen M, Hellstrom M, Scheidl SJ, Abramsson A, Renner O, et al. Transcription profiling of platelet-derived growth factor-B-deficient mouse embryos identifies RGS5 as a novel marker for pericytes and vascular smooth muscle cells. Am J Pathol. 2003;162(3):721-9.

158. Bergers $\mathrm{G}$, Song $\mathrm{S}$. The role of pericytes in blood-vessel formation and maintenance. Neuro Oncol. 2005;7(4):452-64.

159. Mitchell TS, Bradley J, Robinson GS, Shima DT, Ng YS. RGS5 expression is a quantitative measure of pericyte coverage of blood vessels. Angiogenesis. 2008:11(2):141-51.

160. Cho H, Kozasa T, Bondjers C, Betsholtz C, Kehrl JH. Pericyte-specific expression of Rgs5: implications for PDGF and EDG receptor signaling during vascular maturation. FASEB J. 2003;17(3):440-2.

161. Nisancioglu MH, Mahoney WM Jr, Kimmel DD, Schwartz SM, Betsholtz C, Genove G. Generation and characterization of rgs 5 mutant mice. Mol Cell Biol. 2008:28(7):2324-31.

162. Padel T, Roth M, Gaceb A, Li JY, Bjorkqvist M, Paul G. Brain pericyte activation occurs early in Huntington's disease. Exp Neurol. 2018:305:139-50.

163. Ozen I, Deierborg T, Miharada K, Padel T, Englund E, Genove G, et al. Brain pericytes acquire a microglial phenotype after stroke. Acta Neuropathol. 2014;128(3):381-96.

164. Ozen I, Roth M, Barbariga M, Gaceb A, Deierborg T, Genove G, et al. Loss of regulator of $\mathrm{G}$-protein signaling 5 leads to neurovascular protection in stroke. Stroke. 2018:49(9):2182-90.

165. Roth M, Gaceb A, Enstrom A, Padel T, Genove G, Ozen I, et al. Regulator of G-protein signaling 5 regulates the shift from perivascular to parenchymal pericytes in the chronic phase after stroke. FASEB $\mathrm{J}$. 2019;33(8):8990-8.

166. Berger M, Bergers G, Arnold B, Hammerling GJ, Ganss R. Regulator of G-protein signaling-5 induction in pericytes coincides with active vessel remodeling during neovascularization. Blood. 2005;105(3):1094-101.

167. Itoh Y, Suzuki N. Control of brain capillary blood flow. J Cereb Blood Flow Metab. 2012:32(7):1167-76.

168. Nehls V, Drenckhahn D. Heterogeneity of microvascular pericytes for smooth muscle type alpha-actin. J Cell Biol. 1991;113(1):147-54

169. Grant RI, Hartmann DA, Underly RG, Berthiaume AA, Bhat NR, Shih AY. Organizational hierarchy and structural diversity of microvascular pericytes in adult mouse cortex. J Cereb Blood Flow Metab. 2019;39(3):411-25. 
170. Reber F, Gersch U, Funk RW. Blockers of carbonic anhydrase can cause increase of retinal capillary diameter, decrease of extracellular and increase of intracellular $\mathrm{pH}$ in rat retinal organ culture. Graefes Arch Clin Exp Ophthalmol. 2003;241(2):140-8.

171. Verbeek MM, Otte-Holler I, Wesseling P, Ruiter DJ, de Waal RM. Induction of alpha-smooth muscle actin expression in cultured human brain pericytes by transforming growth factor-beta 1. Am J Pathol. 1994;144(2):372-82

172. Boado RJ, Pardridge WM. Differential expression of alpha-actin mRNA and immunoreactive protein in brain microvascular pericytes and smooth muscle cells. J Neurosci Res. 1994;39(4):430-5.

173. Szpak GM, Lewandowska E, Wierzba-Bobrowicz T, Bertrand E, Pasennik E, Mendel T, et al. Small cerebral vessel disease in familial amyloid and non-amyloid angiopathies: FAD-PS-1 (P117L) mutation and CADASIL. Immunohistochemical and ultrastructural studies. Folia Neuropathol. 2007:45(4):192-204

174. Virgintino D, Errede M, Robertson D, Girolamo F, Masciandaro A, Bertossi M. VEGF expression is developmentally regulated during human brain angiogenesis. Histochem Cell Biol. 2003;119(3):227-32.

175. Park JS, Seo J, Kim YO, Lee HS, Jo I. Coordinated regulation of angiopoietin-1 and vascular endothelial growth factor by arsenite in human brain microvascular pericytes: implications of arsenite-induced vascular dysfunction. Toxicology. 2009;264(1-2):26-31.

176. Engelhardt S, Huang SF, Patkar S, Gassmann M, Ogunshola OO. Differential responses of blood-brain barrier associated cells to hypoxia and ischemia: a comparative study. Fluids Barriers CNS. 2015;12:4.

177. Kelleher J, Dickinson A, Cain S, Hu Y, Bates N, Harvey A, et al. Patientspecific iPSC model of a genetic vascular dementia syndrome reveals failure of mural cells to stabilize capillary structures. Stem Cell Reports. 2019;13(5):817-31.

178. Hirooka T, Yamamoto C, Yasutake A, Eto K, Kaji T. Expression of VEGFrelated proteins in cultured human brain microvascular endothelial cells and pericytes after exposure to methylmercury. J Toxicol Sci. 2013;38(6):837-45.

179. Asashima T, lizasa H, Terasaki T, Nakashima E. Rat brain pericyte cell lines expressing beta2-adrenergic receptor, angiotensin II receptor type 1A, klotho, and CXCR4 mRNAs despite having endothelial cell markers. J Cell Physiol. 2003;197(1):69-76.

180. Errede M, Girolamo F, Rizzi M, Bertossi M, Roncali L, Virgintino D. The contribution of CXCL12-expressing radial glia cells to neuro-vascular patterning during human cerebral cortex development. Front Neurosci. 2014;8:324.

181. Virgintino D, Errede M, Rizzi M, Girolamo F, Strippoli M, Walchli T, et al. The CXCL12/CXCR4/CXCR7 ligand-receptor system regulates neuroglio-vascular interactions and vessel growth during human brain development. J Inherit Metab Dis. 2013;36(3):455-66.

182. Song N, Huang Y, Shi H, Yuan S, Ding Y, Song X, et al. Overexpression of platelet-derived growth factor-BB increases tumor pericyte content via stromal-derived factor-1alpha/CXCR4 axis. Cancer Res. 2009;69(15):6057-64.

183. Cheng L, Huang Z, Zhou W, Wu Q, Donnola S, Liu JK, et al. Glioblastoma stem cells generate vascular pericytes to support vessel function and tumor growth. Cell. 2013;153(1):139-52.

184. Nakagawa S, Castro V, Toborek M. Infection of human pericytes by HIV-1 disrupts the integrity of the blood-brain barrier. J Cell Mol Med. 2012;16(12):2950-7

185. Guijarro-Munoz I, Compte M, Alvarez-Cienfuegos A, Alvarez-Vallina L, Sanz L. Lipopolysaccharide activates Toll-like receptor 4 (TLR4)-mediated NF-kappaB signaling pathway and proinflammatory response in human pericytes. J Biol Chem. 2014;289(4):2457-68.

186. Famakin BM, Vemuganti R. Toll-like receptor 4 signaling in focal cerebral ischemia: a focus on the neurovascular unit. Mol Neurobiol. 2020;57(6):2690-701.

187. Rustenhoven J, Jansson D, Smyth LC, Dragunow M. Brain pericytes as mediators of neuroinflammation. Trends Pharmacol Sci. 2017;38(3):291-304

188. Bondjers C, He L, Takemoto M, Norlin J, Asker N, Hellstrom M, et al. Microarray analysis of blood microvessels from PDGF-B and PDGFRbeta mutant mice identifies novel markers for brain pericytes. FASEB J. 2006;20(10):1703-5
189. Nelson PT, Jicha GA, Wang WX, Ighodaro E, Artiushin S, Nichols CG, et al. ABCC9/SUR2 in the brain: implications for hippocampal sclerosis of aging and a potential therapeutic target. Ageing Res Rev. 2015;24(Pt B):111-25.

190. Chen J, Luo Y, Huang H, Wu S, Feng J, Zhang J, et al. CD146 is essential for PDGFRbeta-induced pericyte recruitment. Protein Cell. 2018;9(8):743-7.

191. Crisan M, Yap S, Casteilla L, Chen CW, Corselli M, ParkTS, et al. A perivascular origin for mesenchymal stem cells in multiple human organs. Cell Stem Cell. 2008;3(3):301-13.

192. Verbeek MM, Westphal JR, Ruiter DJ, de Waal RM. T lymphocyte adhesion to human brain pericytes is mediated via very late antigen-4/vascular cell adhesion molecule-1 interactions. J Immunol. 1995;154(11):5876-84.

193. Liebner S, Fischmann A, Rascher G, Duffner F, Grote EH, Kalbacher H, et al. Claudin-1 and claudin-5 expression and tight junction morphology are altered in blood vessels of human glioblastoma multiforme. Acta Neuropathol. 2000;100(3):323-31.

194. Dore-Duffy P, Balabanov R, Rafols J, Swanborg RH. Recovery phase of acute experimental autoimmune encephalomyelitis in rats corresponds to development of endothelial cell unresponsiveness to interferon gamma activation. J Neurosci Res. 1996:44(3):223-34.

195. Nayak RC, Berman AB, George KL, Eisenbarth GS, King GL. A monoclonal antibody (3G5)-defined ganglioside antigen is expressed on the cell surface of microvascular pericytes. J Exp Med. 1988;167(3):1003-15.

196. Burnette JO, White RE. PGI2 opens potassium channels in retinal pericytes by cyclic AMP-stimulated, cross-activation of PKG. Exp Eye Res. 2006;83(6):1359-65.

197. Wong HC, Thompson S, Yu DY, Cringle SJ, Alder VA, Taylor SJ. Comparison of growth rates of bovine retinal and brain microvascular pericytes in different oxygen concentrations in vitro. Aust N Z J Ophthalmol. 1995;23(4):299-308

198. von Tell D, Armulik A, Betsholtz C. Pericytes and vascular stability. Exp Cell Res. 2006;312(5):623-9.

199. Teichert M, Milde L, Holm A, Stanicek L, Gengenbacher N, Savant $\mathrm{S}$, et al. Pericyte-expressed Tie2 controls angiogenesis and vessel maturation. Nat Commun. 2017;8:16106.

200. Hori S, Ohtsuki S, Hosoya K, Nakashima E, Terasaki T. A pericytederived angiopoietin-1 multimeric complex induces occludin gene expression in brain capillary endothelial cells through Tie-2 activation in vitro. J Neurochem. 2004;89(2):503-13.

201. Scholz A, Plate KH, Reiss Y. Angiopoietin-2: a multifaceted cytokine that functions in both angiogenesis and inflammation. Ann N Y Acad Sci. 2015;1347:45-51.

202. Feng Y, vom Hagen F, Pfister F, Djokic S, Hoffmann S, Back W, et al. Impaired pericyte recruitment and abnormal retinal angiogenesis as a result of angiopoietin-2 overexpression. Thromb Haemost. 2007;97(1):99-108.

203. Gurnik S, Devraj K, Macas J, Yamaji M, Starke J, Scholz A, et al. Angiopoietin-2-induced blood-brain barrier compromise and increased stroke size are rescued by VE-PTP-dependent restoration of Tie2 signaling. Acta Neuropathol. 2016;131(5):753-73.

204. Lin TN, Wang CK, Cheung WM, Hsu CY. Induction of angiopoietin and Tie receptor mRNA expression after cerebral ischemia-reperfusion. J Cereb Blood Flow Metab. 2000;20(2):387-95.

205. Yuan X, Caron A, Wu H, Gautron L. Leptin receptor expression in mouse intracranial perivascular cells. Front Neuroanat. 2018;12:4.

206. Ardid-Ruiz A, Harazin A, Barna L, Walter FR, Blade C, Suarez M, et al. The effects of Vitis vinifera $L$. phenolic compounds on a bloodbrain barrier culture model: expression of leptin receptors and protection against cytokine-induced damage. J Ethnopharmacol. 2020;247:112253.

207. MacFadyen J, Savage K, Wienke D, Isacke CM. Endosialin is expressed on stromal fibroblasts and CNS pericytes in mouse embryos and is downregulated during development. Gene Expr Patterns. 2007;7(3):363-9.

208. Bagley RG, Honma N, Weber W, Boutin P, Rouleau C, Shankara S, et al. Endosialin/TEM 1/CD248 is a pericyte marker of embryonic and tumor neovascularization. Microvasc Res. 2008;76(3):180-8. 
209. Simonavicius N, Ashenden M, van Weverwijk A, Lax S, Huso DL, Buckley $C D$, et al. Pericytes promote selective vessel regression to regulate vascular patterning. Blood. 2012;120(7):1516-27.

210. Armulik A, Abramsson A, Betsholtz C. Endothelial/pericyte interactions. Circ Res. 2005;97(6):512-23.

211. Wan Y, Jin HJ, Zhu YY, Fang Z, Mao L, He Q, et al. MicroRNA-149-5p regulates blood-brain barrier permeability after transient middle cerebral artery occlusion in rats by targeting S1PR2 of pericytes. FASEB J. 2018;32(6):3133-48.

212. Nakagawa S, Aruga J. Sphingosine 1-phosphate signaling is involved in impaired blood-brain barrier function in ischemia-reperfusion injury. Mol Neurobiol. 2020;57(3):1594-606.

213. Tang HB, Jiang XJ, Wang C, Liu SC. S1P/S1PR3 signaling mediated proliferation of pericytes via Ras/pERK pathway and CAY10444 had beneficial effects on spinal cord injury. Biochem Biophys Res Commun. 2018:498(4):830-6.

214. Asashima T, lizasa H, Terasaki T, Hosoya K, Tetsuka K, Ueda M, et al. Newly developed rat brain pericyte cell line, TR-PCT1, responds to transforming growth factor-beta1 and beta-glycerophosphate. Eur J Cell Biol. 2002;81(3):145-52.

215. Rustenhoven J, Aalderink M, Scotter EL, Oldfield RL, Bergin PS, Mee EW, et al. TGF-beta1 regulates human brain pericyte inflammatory processes involved in neurovasculature function. J Neuroinflamm. 2016;13:37.

216. Kato $T$, Sekine $Y$, Nozaki H, Uemura M, Ando S, Hirokawa S, et al. Excessive production of transforming growth factor beta1 causes mural cell depletion from cerebral small vessels. Front Aging Neurosci. 2020;12:151.

217. Kuroda J, Ago T, Nishimura A, Nakamura K, Matsuo R, Wakisaka Y, et al. Nox4 is a major source of superoxide production in human brain pericytes. J Vasc Res. 2014;51(6):429-38.

218. Kawamura H, Kobayashi M, Li Q, Yamanishi S, Katsumura K, Minami M, et al. Effects of angiotensin II on the pericyte-containing microvasculature of the rat retina. J Physiol. 2004;561(Pt 3):671-83.

219. Clermont A, Bursell SE, Feener EP. Role of the angiotensin II type 1 receptor in the pathogenesis of diabetic retinopathy: effects of blood pressure control and beyond. J Hypertens Suppl. 2006;24(1):S73-80.

220. Yamagishi S, Takeuchi M, Matsui T, Nakamura K, Imaizumi T, Inoue $H$. Angiotensin II augments advanced glycation end productinduced pericyte apoptosis through RAGE overexpression. FEBS Lett. 2005;579(20):4265-70.

221. Grygorowicz T, Dabrowska-Bouta B, Struzynska L. Administration of an antagonist of $P 2 X 7$ receptor to EAE rats prevents a decrease of expression of claudin-5 in cerebral capillaries. Purinergic Signal. 2018;14(4):385-93.

222. Platania CBM, Giurdanella G, Di Paola L, Leggio GM, Drago F, Salomone S, et al. P2X7 receptor antagonism: implications in diabetic retinopathy. Biochem Pharmacol. 2017;138:130-9.

223. Tigges U, Boroujerdi A, Welser-Alves JV, Milner R. TNF-alpha promotes cerebral pericyte remodeling in vitro, via a switch from alpha1 to alpha2 integrins. J Neuroinflamm. 2013;10:33.

224. Hosford PS, Christie IN, Niranjan A, Aziz Q, Anderson N, Ang R, et al. A critical role for the ATP-sensitive potassium channel subunit KIR6.1 in the control of cerebral blood flow. J Cereb Blood Flow Metab. 2019:39(10):2089-95.

225. Jia C, Keasey MP, Malone HM, Lovins C, Sante RR, Razskazovskiy V, et al. Vitronectin from brain pericytes promotes adult forebrain neurogenesis by stimulating CNTF. Exp Neurol. 2019;312:20-32.

226. Durham JT, Surks HK, Dulmovits BM, Herman IM. Pericyte contractility controls endothelial cell cycle progression and sprouting: insights into angiogenic switch mechanics. Am J Physiol Cell Physiol. 2014;307(9):C878-92.

227. Damisah EC, Hill RA, Tong L, Murray KN, Grutzendler J. A fluoro-Nissl dye identifies pericytes as distinct vascular mural cells during in vivo brain imaging. Nat Neurosci. 2017;20(7):1023-32.

228. Mazare N, Gilbert A, Boulay AC, Rouach N, Cohen-Salmon M. Connexin 30 is expressed in a subtype of mouse brain pericytes. Brain Struct Funct. 2018;223(2):1017-24

229. Nakamura K, Arimura K, Nishimura A, Tachibana M, Yoshikawa $\mathrm{Y}$, Makihara $\mathrm{N}$, et al. Possible involvement of basic FGF in the upregulation of PDGFRbeta in pericytes after ischemic stroke. Brain Res. 2016;1630:98-108.

230. Sakuma R, Takahashi A, Nakano-Doi A, Sawada R, Kamachi S, Beppu $M$, et al. Comparative characterization of ischemia-induced brain multipotent stem cells with mesenchymal stem cells: similarities and differences. Stem Cells Dev. 2018;27(19):1322-38.

231. Gu X, Liu XY, Fagan A, Gonzalez-Toledo ME, Zhao LR. Ultrastructural changes in cerebral capillary pericytes in aged Notch3 mutant transgenic mice. Ultrastruct Pathol. 2012;36(1):48-55.

232. Ghosh M, Balbi M, Hellal F, Dichgans M, Lindauer U, Plesnila N. Pericytes are involved in the pathogenesis of cerebral autosomal dominant arteriopathy with subcortical infarcts and leukoencephalopathy. Ann Neurol. 2015;78(6):887-900.

233. Joutel A. Pathogenesis of CADASIL: transgenic and knock-out mice to probe function and dysfunction of the mutated gene, Notch3, in the cerebrovasculature. BioEssays. 2011;33(1):73-80.

234. Kofler NM, Cuervo H, Uh MK, Murtomaki A, Kitajewski J. Combined deficiency of Notch1 and Notch3 causes pericyte dysfunction, models CADASIL, and results in arteriovenous malformations. Sci Rep. 2015:5:16449.

235. Uemura MT, Ihara M, Maki T, Nakagomi T, Kaji S, Uemura K, et al. Pericyte-derived bone morphogenetic protein 4 underlies white matter damage after chronic hypoperfusion. Brain Pathol. 2018;28(4):521-35.

236. His W. Untersuchungen über die erste Anlage des Wirbelthierleibes: die erste Entwickelung des Hühnchens im Ei. Leipzig: FCW Vogel; 1868.

237. Kastchenko N. Zur Entwicklungsgeschichte der Selachierembryos. Anat Anz. 1888:3:445-67.

238. Platt JB. The development of the cartilaginous skull and of the branchial and hypoglossal musculature in necturus. Morphol Jahrb. 1897;25:377-464.

239. Johnston MC. A radioautographic study of the migration and fate of cranial neural crest cells in the chick embryo. Anat Rec. 1966;156(2):143-55.

240. Le Lievre CS, Le Douarin NM. Mesenchymal derivatives of the neura crest: analysis of chimaeric quail and chick embryos. J Embryol Exp Morphol. 1975;34(1):125-54.

241. Noden DM. The role of the neural crest in patterning of avian cranial skeletal, connective, and muscle tissues. Dev Biol. 1983:96(1):144-65.

242. Couly GF, Coltey PM, Le Douarin NM. The triple origin of skull in higher vertebrates: a study in quail-chick chimeras. Development. 1993;117(2):409-29.

243. Couly G. Cephalic angiogenesis. Ann Dermatol Venereol. 1996;123(4):234

244. Kontges G, Lumsden A. Rhombencephalic neural crest segmentation is preserved throughout craniofacial ontogeny. Development. 1996:122(10):3229-42.

245. Roncali L, Virgintino D, Coltey P, Bertossi M, Errede M, Ribatti D, et al. Morphological aspects of the vascularization in intraventricular neural transplants from embryo to embryo. Anat Embryol. 1996;193(3):191-203.

246. Sims DE. Recent advances in pericyte biology-implications for health and disease. Can J Cardiol. 1991;7(10):431-43.

247. Sims DE. Diversity within pericytes. Clin Exp Pharmacol Physiol. 2000;27(10):842-6.

248. Foster K, Sheridan J, Veiga-Fernandes H, Roderick K, Pachnis V, Adams $\mathrm{R}$, et al. Contribution of neural crest-derived cells in the embryonic and adult thymus. J Immunol. 2008;180(5):3183-9.

249. Muller SM, Stolt CC, Terszowski G, Blum C, Amagai T, Kessaris N, et al. Neural crest origin of perivascular mesenchyme in the adult thymus. $J$ Immunol. 2008;180(8):5344-51.

250. Zachariah MA, Cyster JG. Neural crest-derived pericytes promote egress of mature thymocytes at the corticomedullary junction. Science. 2010;328(5982):1129-35.

251. Simon C, Lickert H, Gotz M, Dimou L. Sox10-iCreERT2: a mouse line to inducibly trace the neural crest and oligodendrocyte lineage. Genesis. 2012:50(6):506-15.

252. Trost A, Schroedl F, Lange S, Rivera FJ, Tempfer H, Korntner S, et al. Neural crest origin of retinal and choroidal pericytes. Invest Ophthalmol Vis Sci. 2013:54(13):7910-21. 
253. Couly GF, Coltey PM, Le Douarin NM. The developmental fate of the cephalic mesoderm in quail-chick chimeras. Development. 1992;114(1):1-15.

254. Couly G, Coltey P, Eichmann A, Le Douarin NM. The angiogenic potentials of the cephalic mesoderm and the origin of brain and head blood vessels. Mech Dev. 1995;53(1):97-112.

255. Reyahi A, Nik AM, Ghiami M, Gritli-Linde A, Ponten F, Johansson BR, et al. Foxf2 is required for brain pericyte differentiation and development and maintenance of the blood-brain barrier. Dev Cell. 2015;34(1):19-32.

256. Jeske R, Albo J, Marzano M, Bejoy J, Li Y. Engineering brain-specific pericytes from human pluripotent stem cells. Tissue Eng Part B Rev. 2020;26(4):367-82.

257. Cuevas P, Gutierrez-Diaz JA, Reimers D, Dujovny M, Diaz FG, Ausman J. Pericyte endothelial gap junctions in human cerebral capillaries. Anat Embryol. 1984;170(2):155-9.

258. Dohgu S, Takata F, Yamauchi A, Nakagawa S, Egawa T, Naito M, et al. Brain pericytes contribute to the induction and up-regulation of blood-brain barrier functions through transforming growth factor-beta production. Brain Res. 2005;1038(2):208-15.

259. Nakagawa S, Deli MA, Nakao S, Honda M, Hayashi K, Nakaoke R, et al. Pericytes from brain microvessels strengthen the barrier integrity in primary cultures of rat brain endothelial cells. Cell Mol Neurobiol. 2007;27(6):687-94.

260. Nakamura K, Kamouchi M, Kitazono T, Kuroda J, Matsuo R, Hagiwara N et al. Role of NHE1 in calcium signaling and cell proliferation in human CNS pericytes. Am J Physiol Heart Circ Physiol. 2008;294(4):H1700-7.

261. Shimizu F, Sano Y, Maeda T, Abe MA, Nakayama H, Takahashi R, et al. Peripheral nerve pericytes originating from the blood-nerve barrier expresses tight junctional molecules and transporters as barrier-forming cells. J Cell Physiol. 2008;217(2):388-99.

262. Armulik A, Genove G, Mae M, Nisancioglu MH, Wallgard E, Niau$\operatorname{det} C$, et al. Pericytes regulate the blood-brain barrier. Nature. 2010;468(7323):557-61.

263. Bell RD, Winkler EA, Sagare AP, Singh I, LaRue B, Deane R, et al. Pericytes control key neurovascular functions and neuronal phenotype in the adult brain and during brain aging. Neuron. 2010;68(3):409-27.

264. Daneman R, Zhou L, Kebede AA, Barres BA. Pericytes are required for blood-brain barrier integrity during embryogenesis. Nature. 2010;468(7323):562-6.

265. Krueger M, Bechmann I. CNS pericytes: concepts, misconceptions, and a way out. Glia. 2010;58(1):1-10.

266. Al Ahmad A, Taboada CB, Gassmann M, Ogunshola OO. Astrocytes and pericytes differentially modulate blood-brain barrier characteristics during development and hypoxic insult. J Cereb Blood Flow Metab. 2011;31(2):693-705

267. Kamouchi M, Ago T, Kitazono T. Brain pericytes: emerging concepts and functional roles in brain homeostasis. Cell Mol Neurobiol. 2011;31(2):175-93.

268. Thanabalasundaram G, Schneidewind J, Pieper C, Galla HJ. The impact of pericytes on the blood-brain barrier integrity depends critically on the pericyte differentiation stage. Int J Biochem Cell Biol. 2011;43(9):1284-93.

269. Alcendor DJ. Interactions between amyloid-beta proteins and human brain pericytes: implications for the pathobiology of Alzheimer's disease. J Clin Med. 2020;9(5):1490.

270. Engelhardt B, Liebner S. Novel insights into the development and maintenance of the blood-brain barrier. Cell Tissue Res. 2014:355(3):687-99.

271. Lee RT, Nagai H, Nakaya Y, Sheng G, Trainor PA, Weston JA, et al. Cell delamination in the mesencephalic neural fold and its implication for the origin of ectomesenchyme. Development. 2013;140(24):4890-902

272. Lojewski X, Srimasorn S, Rauh J, Francke S, Wobus M, Taylor V, et al. Perivascular mesenchymal stem cells from the adult human brain harbor no instrinsic neuroectodermal but high mesodermal differentiation potential. Stem Cells Transl Med. 2015:4(10):1223-33.

273. Stallcup WB, Cohn M. Correlation of surface antigens and cell type in cloned cell lines from the rat central nervous system. Exp Cell Res. 1976;98(2):285-97.

274. Nishiyama A, Lin XH, Giese N, Heldin CH, Stallcup WB. Interaction between NG2 proteoglycan and PDGF alpha-receptor on O2A progenitor cells is required for optimal response to PDGF. J Neurosc Res. 1996:43(3):315-30.

275. Goretzki L, Burg MA, Grako KA, Stallcup WB. High-affinity binding of basic fibroblast growth factor and platelet-derived growth factor-AA to the core protein of the NG2 proteoglycan. J Biol Chem. 1999;274(24):16831-7.

276. Nishiyama A, Lee A, Brunquell CB. NG2 (Cspg4) cell surface proteoglycan on oligodendrocyte progenitor cells in the developing and mature nervous system. In: Pruszak J, editor. Neural Surface antigens, from basic towards biomedical applications. Neural Surface Antigens. 1st ed. Amsterdam: Academic Press; 2015.

277. O'Rahilly R, Muller F. Neurulation in the normal human embryo. Ciba Found Symp. 1994;181:70-82 discussion -9.

278. Norman MG, O'Kusky JR. The growth and development of microvasculature in human cerebral cortex. J Neuropathol Exp Neurol. 1986:45(3):222-32.

279. Couly GF, Le Douarin NM. Mapping of the early neural primordium in quail-chick chimeras. II. The prosencephalic neural plate and neural folds: implications for the genesis of cephalic human congenital abnormalities. Dev Biol. 1987;120(1):198-214.

280. Engelhardt B. Development of the blood-brain barrier. Cell Tissue Res. 2003;314(1):119-29.

281. Risau W. Embryonic angiogenesis factors. Pharmacol Ther. 1991;51(3):371-6

282. Breier G, Albrecht U, Sterrer S, Risau W. Expression of vascular endothelial growth factor during embryonic angiogenesis and endothelial cell differentiation. Development. 1992;114(2):521-32.

283. Millauer B, Wizigmann-Voos S, Schnurch H, Martinez R, Moller NP, Risau W, et al. High affinity VEGF binding and developmental expression suggest Flk-1 as a major regulator of vasculogenesis and angiogenesis. Cell. 1993:72(6):835-46.

284. Risau W, Esser S, Engelhardt B. Differentiation of blood-brain barrier endothelial cells. Pathol Biol (Paris). 1998:46(3):171-5.

285. Virgintino D, Errede M, Robertson D, Capobianco C, Girolamo F, Vimercati $A$, et al. Immunolocalization of tight junction proteins in the adult and developing human brain. Histochem Cell Biol. 2004;122(1):51-9.

286. Virgintino D, Robertson D, Benagiano V, Errede M, Bertossi M, Ambrosi $\mathrm{G}$, et al. Immunogold cytochemistry of the blood-brain barrier glucose transporter GLUT1 and endogenous albumin in the developing human brain. Brain Res Dev Brain Res. 2000;123(1):95-101.

287. Virgintino D, Robertson D, Errede M, Benagiano V, Girolamo F, Maio-

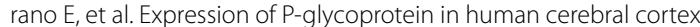
microvessels. J Histochem Cytochem. 2002;50(12):1671-6.

288. Umans RA, Henson HE, Mu F, Parupalli C, Ju B, Peters JL, et al. CNS angiogenesis and barriergenesis occur simultaneously. Dev Biol. 2017;425(2):101-8.

289. Virgintino D, Ozerdem U, Girolamo F, Roncali L, Stallcup WB, Perris R. Reversal of cellular roles in angiogenesis: implications for anti-angiogenic therapy. J Vasc Res. 2008;45(2):129-31.

290. Stratman AN, Malotte KM, Mahan RD, Davis MJ, Davis GE. Pericyte recruitment during vasculogenic tube assembly stimulates endothelial basement membrane matrix formation. Blood. 2009;114(24):5091-101.

291. Stapor PC, Sweat RS, Dashti DC, Betancourt AM, Murfee WL. Pericyte dynamics during angiogenesis: new insights from new identities. J Vasc Res. 2014;51(3):163-74.

292. Nehls V, Denzer K, Drenckhahn D. Pericyte involvement in capillary sprouting during angiogenesis in situ. Cell Tissue Res. 1992:270(3):469-74.

293. Nystrom HC, Lindblom P, Wickman A, Andersson I, Norlin J, Faldt J, et al. Platelet-derived growth factor $B$ retention is essential for development of normal structure and function of conduit vessels and capillaries. Cardiovasc Res. 2006;71(3):557-65.

294. Osswald M, Solecki G, Wick W, Winkler F. A malignant cellular network in gliomas: potential clinical implications. Neuro Oncol. 2016;18(4):479-85.

295. Fukushi J, Makagiansar IT, Stallcup WB. NG2 proteoglycan promotes endothelial cell motility and angiogenesis via engagement of galectin-3 and alpha3beta1 integrin. Mol Biol Cell. 2004;15(8):3580-90.

296. Gaceb A, Ozen I, Padel T, Barbariga M, Paul G. Pericytes secrete proregenerative molecules in response to platelet-derived growth factorBB. J Cereb Blood Flow Metab. 2018;38(1):45-57. 
297. Yu Y, Fang H, Qiu Z, Xia Z, Zhou B. DHA attenuates hypoxia/reoxygenation injury by activating SSeCKS in human cerebrovascular pericytes. Neurochem Res. 2020;45(2):310-21.

298. Kang TY, Bocci F, Jolly MK, Levine H, Onuchic JN, Levchenko A. Pericytes enable effective angiogenesis in the presence of proinflammatory signals. Proc Natl Acad Sci USA. 2019;1 16(47):23551-61.

299. Birner P, Piribauer M, Fischer I, Gatterbauer B, Marosi C, Ambros PF, et al. Vascular patterns in glioblastoma influence clinical outcome and associate with variable expression of angiogenic proteins: evidence for distinct angiogenic subtypes. Brain Pathol. 2003;13(2):133-43.

300. Liu XM, Zhang QP, Mu YG, Zhang XH, Sai K, Pang JC, et al. Clinical significance of vasculogenic mimicry in human gliomas. J Neurooncol. 2011;105(2):173-9.

301. Sun H, Guo D, Su Y, Yu D, Wang Q, Wang T, et al. Hyperplasia of pericytes is one of the main characteristics of microvascular architecture in malignant glioma. PLoS ONE. 2014;9(12):e114246.

302. Roehlecke C, Schmidt MHH. Tunneling nanotubes and tumor microtubes in cancer. Cancers. 2020;12(4):857.

303. Etchevers HC, Couly G, Vincent C, Le Douarin NM. Anterior cephalic neural crest is required for forebrain viability. Development. 1999;126(16):3533-43.

304. Ozerdem U, Monosov E, Stallcup WB. NG2 proteoglycan expression by pericytes in pathological microvasculature. Microvasc Res 2002;63(1):129-34.

305. Sehgal R. Neural crest cells and the mesentery. Mesentery Peritoneum. 2018;2(1):3.

306. Nishiyama C, Uesaka T, Manabe T, Yonekura Y, Nagasawa T, Newgreen DF, et al. Trans-mesenteric neural crest cells are the principal source of the colonic enteric nervous system. Nat Neurosci. 2012;15(9):1211-8.

307. McKinney MC, Stark DA, Teddy J, Kulesa PM. Neural crest cell communication involves an exchange of cytoplasmic material through cellular bridges revealed by photoconversion of KikGR. Dev Dyn. 2011;240(6):1391-401.

308. Farahani RM, Sarrafpour B, Simonian M, Li Q, Hunter N. Directed gliaassisted angiogenesis in a mature neurosensory structure: pericytes mediate an adaptive response in human dental pulp that maintains blood-barrier function. J Comp Neurol. 2012;520(17):3803-26.

309. Nishiyama A, Dahlin KJ, Prince JT, Johnstone SR, Stallcup WB. The primary structure of NG2, a novel membrane-spanning proteoglycan. J Cell Biol. 1991;114(2):359-71.

310. Stallcup WB, Dahlin K, Healy P. Interaction of the NG2 chondroitin sulfate proteoglycan with type VI collagen. J Cell Biol. 1990;111(6 Pt 2):3177-88

311. Burg MA, Nishiyama A, Stallcup WB. A central segment of the NG2 proteoglycan is critical for the ability of glioma cells to bind and migrate toward type VI collagen. Exp Cell Res. 1997;235(1):254-64.

312. Tillet E, Ruggiero F, Nishiyama A, Stallcup WB. The membranespanning proteoglycan NG2 binds to collagens $V$ and $V 1$ through the central nonglobular domain of its core protein. J Biol Chem. 1997;272(16):10769-76.

313. Grako KA, Ochiya T, Barritt D, Nishiyama A, Stallcup WB. PDGF (alpha)receptor is unresponsive to PDGF-AA in aortic smooth muscle cells from the NG2 knockout mouse. J Cell Sci. 1999;112(Pt 6):905-15.

314. Asher RA, Morgenstern DA, Properzi F, Nishiyama A, Levine JM, Fawcett JW. Two separate metalloproteinase activities are responsible for the shedding and processing of the NG2 proteoglycan in vitro. Mol Cell Neurosci. 2005;29(1):82-96.

315. Joo NE, Miao D, Bermudez M, Stallcup WB, Kapila YL. Shedding of NG2 by MMP-13 attenuates anoikis. DNA Cell Biol. 2014;33(12):854-62.

316. Sakry D, Neitz A, Singh J, Frischknecht R, Marongiu D, Biname F, et al. Oligodendrocyte precursor cells modulate the neuronal network by activity-dependent ectodomain cleavage of glial NG2. PLoS Biol. 2014;12(11):e1001993.

317. Schultz N, Nielsen HM, Minthon L, Wennstrom M. Involvement of matrix metalloproteinase-9 in amyloid-beta 1-42-induced shedding of the pericyte proteoglycan NG2. J Neuropathol Exp Neurol. 2014;73(7):684-92.

318. Wennstrom M, Janelidze S, Bay-Richter C, Minthon L, Brundin L. Pro-inflammatory cytokines reduce the proliferation of NG2 cells and increase shedding of NG2 in vivo and in vitro. PLOS ONE. 2014:9(10):e109387.
319. Nishihara T, Remacle AG, Angert M, Shubayev I, Shiryaev SA, Liu H, et al. Matrix metalloproteinase-14 both sheds cell surface neuronal glial antigen 2 (NG2) proteoglycan on macrophages and governs the response to peripheral nerve injury. J Biol Chem. 2015;290(6):3693-707.

320. Schafer MKE, Tegeder I. NG2/CSPG4 and progranulin in the posttraumatic glial scar. Matrix Biol. 2018;68-69:571-88.

321. Nishiyama A, Lin XH, Stallcup WB. Generation of truncated forms of the NG2 proteoglycan by cell surface proteolysis. Mol Biol Cell. 1995;6(12):1819-32

322. Sakry D, Trotter J. The role of the NG2 proteoglycan in OPC and CNS network function. Brain Res. 2016;1638(Pt B):161-6.

323. Levine JM, Nishiyama A. The NG2 chondroitin sulfate proteoglycan: a multifunctional proteoglycan associated with immature cells. Perspect Dev Neurobiol. 1996;3(4):245-59.

324. Psachoulia K, Jamen F, Young KM, Richardson WD. Cell cycle dynamics of NG2 cells in the postnatal and ageing brain. Neuron Glia Biol. 2009;5(3-4):57-67.

325. Girolamo F, Ferrara G, Strippoli M, Rizzi M, Errede M, Trojano M, et al. Cerebral cortex demyelination and oligodendrocyte precursor response to experimental autoimmune encephalomyelitis. Neurobiol Dis. 2011;43(3):678-89.

326. Biname F, Sakry D, Dimou L, Jolivel V, Trotter J. NG2 regulates directional migration of oligodendrocyte precursor cells via Rho GTPases and polarity complex proteins. J Neurosci. 2013;33(26):10858-74.

327. Maus F, Sakry D, Biname F, Karram K, Rajalingam K, Watts C, et al. The NG2 proteoglycan protects oligodendrocyte precursor cells against oxidative stress via interaction with OMI/HtrA2. PLoS ONE. 2015;10(9):e0137311.

328. Butt AM, Duncan A, Hornby MF, Kirvell SL, Hunter A, Levine JM, et al. Cells expressing the NG2 antigen contact nodes of Ranvier in adult CNS white matter. Glia. 1999:26(1):84-91.

329. Bergles DE, Roberts JD, Somogyi P, Jahr CE. Glutamatergic synapses on oligodendrocyte precursor cells in the hippocampus. Nature. 2000;405(6783):187-91.

330. Sakry D, Karram K, Trotter J. Synapses between NG2 glia and neurons. J Anat. 2011;219(1):2-7.

331. Barres BA, Koroshetz WJ, Swartz KJ, Chun LL, Corey DP. Ion channel expression by white matter glia: the O-2A glial progenitor cell. Neuron. 1990;4(4):507-24

332. NayakT, Trotter J, Sakry D. The intracellular cleavage product of the NG2 proteoglycan modulates translation and cell-cycle kinetics via effects on mTORC1/FMRP signaling. Front Cell Neurosci. 2018:12:231.

333. Nielsen HM, Ek D, Avdic U, Orbjorn C, Hansson O, Netherlands brain B, et al. NG2 cells, a new trail for Alzheimer's disease mechanisms? Acta Neuropathol Commun. 2013;1:7

334. Bell RD, Deane R, Chow N, Long X, Sagare A, Singh I, et al. SRF and myocardin regulate LRP-mediated amyloid-beta clearance in brain vascular cells. Nat Cell Biol. 2009;1 1(2):143-53.

335. Winkler EA, Sagare AP, Zlokovic BV. The pericyte: a forgotten cell type with important implications for Alzheimer's disease? Brain Pathol. 2014;24(4):371-86.

336. Salmina AB, Komleva YK, Lopatina OL, Birbrair A. Pericytes in Alzheimer's disease: novel clues to cerebral amyloid angiopathy pathogenesis. Adv Exp Med Biol. 2019;1147:147-66.

337. Miyagawa K, Shi M, Chen PI, Hennigs JK, Zhao Z, Wang M, et al. Smooth muscle contact drives endothelial regeneration by BMPR2Notch1-mediated metabolic and epigenetic changes. Circ Res. 2019:124(2):211-24

338. Olesnicky Killian EC, Birkholz DA, Artinger KB. A role for chemokine signaling in neural crest cell migration and craniofacial development. Dev Biol. 2009;333(1):161-72.

339. McLennan R, Kulesa PM. In vivo analysis reveals a critical role for neuropilin-1 in cranial neural crest cell migration in chick. Dev Biol. 2007:301(1):227-39.

340. Rezzoug F, Seelan RS, Bhattacherjee V, Greene RM, Pisano MM. Chemokine-mediated migration of mesencephalic neural crest cells. Cytokine. 2011;56(3):760-8.

341. Bodnar RJ, Rodgers ME, Chen WC, Wells A. Pericyte regulation of vascular remodeling through the CXC receptor 3. Arterioscler Thromb VasC Biol. 2013;33(12):2818-29. 
342. Nakagawa S, Deli MA, Kawaguchi H, Shimizudani T, Shimono T, Kittel A, et al. A new blood-brain barrier model using primary rat brain endothelial cells, pericytes and astrocytes. Neurochem Int. 2009;54(3-4):253-63.

343. Cecchelli R, Aday S, Sevin E, Almeida C, Culot M, Dehouck L, et al. A stable and reproducible human blood-brain barrier model derived from hematopoietic stem cells. PLoS ONE. 2014;9(6):e99733.

344. Griffin C, Bajpai R. Neural crest-derived human cranial pericytes model primary forebrain pericytes and predict disease-specific cranial vasculature defects. SSRN. 2017:3189103.

345. Jamieson JJ, Linville RM, Ding YY, Gerecht S, Searson PC. Role of iPSCderived pericytes on barrier function of iPSC-derived brain microvascular endothelial cells in 2D and 3D. Fluids Barriers CNS. 2019;16(1):15.

346. Na IK, Scheibenbogen C, Adam C, Stroux A, Ghadjar P, Thiel E, et al. Nuclear expression of CXCR4 in tumor cells of non-small cell lung cancer is correlated with lymph node metastasis. Hum Pathol 2008;39(12):1751-5.

347. Berger O, Li G, Han SM, Paredes M, Pleasure SJ. Expression of SDF-1 and CXCR4 during reorganization of the postnatal dentate gyrus. Dev Neurosci. 2007;29(1-2):48-58.

\section{Publisher's Note}

Springer Nature remains neutral with regard to jurisdictional claims in published maps and institutional affiliations.
Ready to submit your research? Choose BMC and benefit from:

- fast, convenient online submission

- thorough peer review by experienced researchers in your field

- rapid publication on acceptance

- support for research data, including large and complex data types

- gold Open Access which fosters wider collaboration and increased citations

- maximum visibility for your research: over $100 \mathrm{M}$ website views per year

At BMC, research is always in progress.

Learn more biomedcentral.com/submissions 